\title{
A comprehensive study on the microstructure and mechanical properties of arc girth welded joints of spiral welded high strength API X70 steel pipe
}

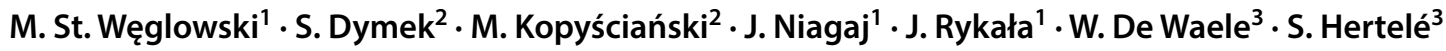

Received: 9 March 2019 / Accepted: 30 November 2019 / Published online: 18 February 2020

(c) The Author(s) 2020

\begin{abstract}
In the paper, the effect of welding technology on the microstructure and mechanical properties of girth welded joints was presented. Metallographic examinations based on light microscopy and SEM were conducted on girth welded joints of API X70 steel pipe. Research has shown that microstructure of the heat-affected zone (HAZ) of MMA girth welded joints is not homogeneous and depends on the thermal history of each area during the welding process. Near the fusion line the zone is coarse, and further away there is a fine-grained zone. In the area of root passes the microstructure consists of recrystallized ferrite grains unlike to cap passes where the fine bainitic microstructure can be observed. In the case of MAG girth welded joints, the weld microstructure consists of primary austenite grains. The primary austenite boundaries serve as nucleation sites of ferrite. The microstructure of the HAZ varies continuously from a coarse-to fine-grained microstructure of the base material. The results of mechanical properties of girth welded joints are also presented. The hardness and strength of arc welded joints depend on welding filler materials as well as welding technology. The results of hardness distribution of MMA and MAG girth welded joints confirmed the results of microstructural evaluation.
\end{abstract}

\section{Introduction}

The strong demand for natural gas and oil products in European, North American and Asian countries is expected for the immediate future [1]. This requires a rapid development of cost-effective transportation means to economically exploit gas and oil fields located in remote areas, in some cases $5000-6000 \mathrm{~km}$ away from the market or oil and gas facilities areas, across harsh environment. A competitive option is the application of high-pressure natural gas and oil products transmission pipelines. In particular, for natural gas transportation pipelines over long distances, the use of pipes fabricated from high strength steel (HSS) such as

\footnotetext{
M. St. Węglowski

marek.weglowski@is.gliwice.pl

1 Lukasiewicz - Institute of Welding, B1. Czesława Str. 16-18, 44-100 Gliwice, Poland

2 Faculty of Metal Engineering and Industrial Computer Science, AGH University of Science and Technology, Czarnowiejska Str. 66, 30-054 Kraków, Poland
}

3 Department EEMMeCS, Soete Laboratory, Universiteit Gent, Technologiepark-Zwijnaarde 903, 9052 Zwijnaarde, Belgium
API X70 is very attractive from a technical and economical point of view. The basic advantages of API X70 grade are high strength and toughness, higher strength/weight ratio, good formability but also good weldability [2]. Weldability, being a very important technological factor of pipeline steels, depends on the metallurgical purity and total content of carbon and alloying elements. These factors govern the crack sensitivity of welded joints during the solidification process of a weld metal. Hot cracking results from the increased concentration of such impurities like $\mathrm{P}$ and $\mathrm{S}$ or non-metallic inclusions.

Cold cracks (hydrogen-induced cracks) occur during the cooling stage of welded joints and are formed by the microscopic stresses arising from martensitic transformation of austenite acting in tandem with dissolved hydrogen in the weld metal/HAZ.

Pipes produced from HSS containing low amounts of sulphur and phosphorus and limited number of nonmetallic inclusions exhibit low hot-cracking susceptibility, however, susceptibility to the formation of cold cracks is higher. That is why the primary interest is to obtain the best possible combination of strength and toughness. This can be realized by the selection of appropriate chemical 
composition as well as thermomechanical processing that produces suitable microstructure.

A typical high strength low alloy steel contains $0.07-0.12 \%$ carbon, up to $2 \%$ manganese and small additions of niobium, vanadium and titanium (all usually max. $0.1 \%$ ) in various combinations. To other elements that might be present in such a steel belong molybdenum, zirconium, boron, aluminium, nitrogen and occasionally rare earth metals [3]. The microalloying elements are used to refine the grain microstructure and/or facilitate dispersion strengthening through precipitation. They are normally regarded as having a low effect on hardenability. Controlled additions of sulphur, and occasionally tellurium, are also added to improve the machinability [3].

The steel is subjected preferably to thermomechanical rolling process, also known as controlled rolling, possibly with accelerated cooling, which maximises grain refinement as a basis for improving strength and simultaneously decreasing ductile to brittle transition (DBTT) temperature. Before thermomechanical processing, the steel was annealed at the austenite temperature range to dissolve all precipitates and bring alloying elements into solid solution; after forming, the material must be quickly cooled to from 600 to $540{ }^{\circ} \mathrm{C}$. The details regarding the thermomechanical processing (controlled rolling) and accelerated cooling procedure applied to the API X70 steel are presented in Ref. [4]. However, depending on the cooling media, a specific microstructure was obtained that results in a different set of mechanical properties comparing to properties obtained using a classic air cooling procedure (ferrite or ferrite + pearlite) [4]. It is worthy of notice that the decrease in grain size caused increase in the strength of the material [5].

Li et al. [6] revealed that the microstructure of the API $\mathrm{X} 70$ steel is composed of acicular ferrite (AF), polygonal ferrite (PF) and quasi polygonal ferrite (QPF). The average grain size is about $10 \mu \mathrm{m}$ but the smallest grains exhibit diameters 3-5 $\mu \mathrm{m}$. In another paper, Shin and co-workers [7] reported that the microstructure of the API X70 steel consists of acicular ferrite and granular bainite with the presence of a small amount of martensite-austenite constituent (MA). For other technological parameters of the thermomechanical process the microstructure of the API $\mathrm{X} 70$ steel is composed of polygonal ferrite, acicular ferrite, upper bainite (UB) and a small amount of martensite-austenite constituent as well as cementite. Also Sohn and coworkers [8] revealed that the microstructure of API X70 steel is composed of quasi-polygonal ferrite, acicular ferrite, granular bainite, pearlite, and martensite-austenite constituent. Wang and co-workers [9] showed that the microstructure consists of ferrite $(\alpha)$, carbides at ferrite GBs, some pearlite and some small precipitates that were found inside ferrite grains. The precipitates containing $\mathrm{Ti}$,
$\mathrm{Nb}, \mathrm{V}$ and $\mathrm{N}$ were identified as complex carbo-nitrides and designated as $(\mathrm{Ti}, \mathrm{Nb}, \mathrm{V})(\mathrm{C}, \mathrm{N})$.

\section{Literature survey}

Many attempts have been made to analyse the microstructure of API X70 steel welded joints. However, there is a lack of a more systematic metallographic investigations comprising the base material, HAZ as well as weld metal with relation to mechanical properties [10-20]. Ghomashchi and co-workers [10] revealed that the microstructure of arc girth welded joint of the API X70 steel produced by the manual metal arc (MMA) welding with E6010 cellulosic electrodes are composed of Widmanstätten and acicular ferrites, lamellar pearlite and aggregated ferrite-carbide. The upper and lower bainite morphologies were also detected. The microstructure of submerged-arc welds consisted of ferrite with mixed morphologies, small amounts of pearlite and martensite-austenite micro-constituents [10]. The formation of pearlite lamellae could not be completed in the weld region. Several types of precipitates including spherical, cubical, fine and irregular titanium carbonitrides were found in the microstructure. These precipitates (inclusions) constituted preferential sites for the nucleation of acicular ferrite. The size of cubi$\mathrm{cal} / \mathrm{spherical}$ and fine precipitates was between 70-100 and $10-20 \mathrm{~nm}$, respectively. The low energy interface between an inclusion and matrix as well as the depletion of carbon in austenite were proposed to be responsible for the nucleation mechanisms of acicular ferrite from nano-sized inclusions. Also Bordbar et al. [11] revealed that the HAZ microstructure developed during submerged arc welding contained a mixture of acicular ferrite and bainitic ferrite. The grain size in the HAZ was considerably greater than in the base material. The weld metal zone microstructure contained mainly acicular ferrite and grain boundary ferrites (GBFs) in the form of Widmanstatten and polygonal ferrites. Moreover, Mohammadijoo et al. [12] revealed that the formation of a lower fraction of fine MA constituents associated with the smaller prior austenite grain resulted in lower micro-hardness values along the coarse-grained HAZ of the steel welded by conventional tandem submerged arc welding + cold-wire relative to that welded by conventional tandem submerged arc welding. The changes in the microstructure characteristics and micro-hardness in the coarse-grained HAZ are essentially attributed to the reduction in welding heat input and an increase in the cooling rate with a corresponding reduction in the retention time in the austenitic region $\left(1100-1400{ }^{\circ} \mathrm{C}\right)$ by cold wire addition. Also Moraes et al. [13] reported that the TIG welding process produced distinct microstructural features (API 5L X65 steel). The microstructure found 
near the weld centreline, at the centre of the weld metal, displayed coarse columnar grains and composed of acicular ferrite with ferrite with aligned second phase, some polygonal ferrite and grain boundary ferrite. Meanwhile, the HAZ region presented polygonal grains of ferrite with ferrite carbide aggregate, as well as constituents M-A. Moreover, Giorgetti et al. [14] found that the HAZ of butt welded joint (MMA and TIG welded joints of API X70 steel) is composed of relatively coarse grains of polygonal ferrite with some dispersed pearlite, preferentially at the grain boundaries. On the other hand, the microstructure of weld metal in an intermediate zone of filler weld includes mainly acicular ferrite and grain boundary phases such as Widmanstätten and polygonal ferrites. Moreover, the root of the weld consists predominantly of coarse polygonal ferrite grains with pearlite concentrated at the grain boundaries. This is caused by the slow cooling time of the region due to the successive filler weld passes. An information about the microstructure of MMA welded joint (API X70 steel) $9 \mathrm{~mm}$ in thickness was provided also by Digheche et al. [15]. They revealed that the microstructure of the HAZ shows fine ferrite grains with some elongated entities. In the weld metal, the region of the root passes contains ferrite grains with some colonies of pearlite, however, region of the cap passes is totally different and contains acicular ferrite and ferrite side plates.

It should be noted that the number of repairs performed on an arc welded joint has influence on the microstructure of HAZ in the API X70 steel. The repairs have an influence on the HAZ width as well as on the grain size. The primary factors that affect the grain size are: temperature, holding time and microalloying elements [16]. Vega et al. [17] found that an increase in the number of repairs may result in increasing the grain size.

The microstructural heterogeneity is also an important factor in welded joints. It is inherent to fusion welds because to melt the weld metal and fuse it with the base metal, heat has to be locally applied. For thicker $(>8 \mathrm{~mm})$ sections, typical for pipelines, weldments are produced in several passes (deposition of multiple layers) resulting in a variety of zones undergoing successive specific heat cycles. In particular, root passes (hot passes), fill passes and cover passes can be distinguished. The heat cycles determine the microstructural transformations that bring about a different stress-strain response. Not only the weldment is heterogeneous due to these transformations but the changes of microstructure also occur in the heat-affected zone $[18,19]$.

In this paper, the metallographic examination based on light and SEM microscopies was made with a special focus on the microstructure in the sub-regions of the girth welded joint of the API X70 steel. The microstructure evaluation was supplemented by the hardness distribution maps that reveal the heterogeneity of girth welded joints. The mechanical properties were also determined. The purpose of the study was to determine the differences of microstructure of the girth welded joints depending on the welding technology and the applied filler material.

\section{Experimental details}

\subsection{Test material}

The investigated material was in the form of pipe made of the API grade X70 steel with a diameter of $914.4 \mathrm{~mm}$ $\left(36^{\prime \prime}\right)$ and the wall thickness of $17.1 \mathrm{~mm}$ formed by spiral welding (Fig. 1). The chemical composition of the steel was determined using an optical emission spectrometer with spark discharge Q4 TASMAN 170 (Bruker). The chemical composition and mechanical properties of steel are given in Tables 1,2 and 3. The investigated material met the requirements of the EN ISO 3183:2013-05 standard [20] for the L485M steel.

Welding trials were performed using MMA (111) and MAG (135) welding processes, in accordance with the developed individual welded joints technological instruction WPS. Three coated electrodes (FOX EV65, AWS A5.5: E8018-GH4R [21, 22], FOX EV85, AWS A5.5: E8018GH4R [22, 23] and Pipeliner 6P+, AWS A5.1: E6010 [24, 25] for root passes) and two welding wires (Carbofil MnMo, AWS A5.28: ER 80S-D2 [26, 27], LMN MoNiVa, AWS A5.28: ER100S-G [27, 28]) to weld the girth welded joints were used.

For MMA welding process the INVERTEC V270 (Lincoln Electric) welding machine was applied. The basic technological parameters were as follow: maximum welding current $270 \mathrm{~A}$ at $35 \%$ duty cycle and $200 \mathrm{~A}$ for $100 \%$, welding current range 5-270 A. Meanwhile, for MAG welding S5 SpeedPulse XT (Lorch) was used. The basic technological

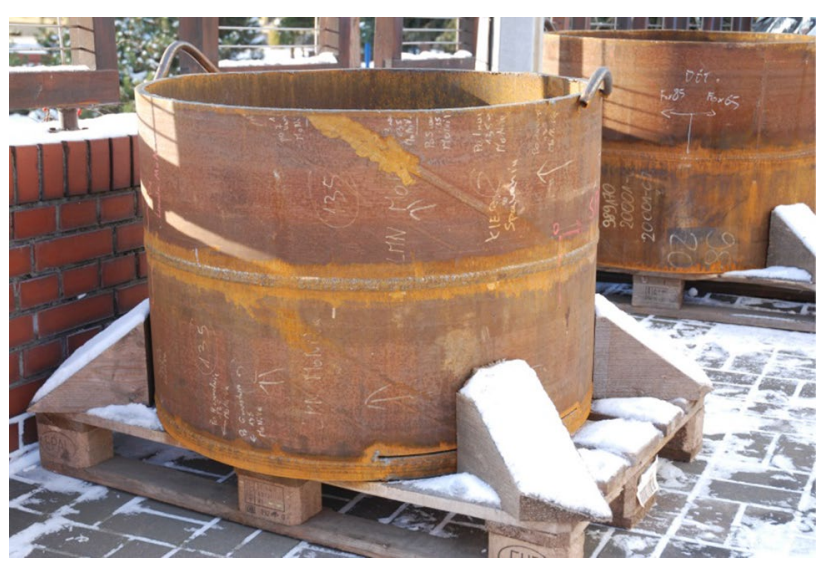

Fig. 1 Girth MMA and MAG welded joints of API X70 steel 
Table 1 Chemical composition of API 5L X70 (L485) steel (wt\%)

Chemical composition

\begin{tabular}{lllllllll}
\hline $\mathrm{C}$ & $\mathrm{Mn}$ & $\mathrm{Si}$ & $\mathrm{P}$ & $\mathrm{S}$ & $\mathrm{Cr}$ & $\mathrm{Ni}$ & $\mathrm{Mo}$ & $\mathrm{Cu}$ \\
\hline 0.101 & 1.774 & 0.340 & 0.013 & 0.004 & 0.039 & 0.164 & 0.009 & 0.118 \\
\hline $\mathrm{Co}$ & $\mathrm{Al}$ & $\mathrm{V}$ & $\mathrm{Ti}$ & $\mathrm{B}$ & $\mathrm{Nb}$ & $\mathrm{Zr}$ & $\mathrm{W}$ & $\mathrm{Zr}$ \\
\hline 0.011 & 0.037 & 0.008 & 0.033 & 0.0003 & 0.051 & 0.0022 & 0.026 & 0.002 \\
\hline
\end{tabular}

Table 2 The mechanical properties of API 5L X70 (L485M) steel

\begin{tabular}{|c|c|c|c|c|c|c|c|c|c|c|}
\hline \multicolumn{4}{|c|}{ Specimen } & \multicolumn{7}{|c|}{ Mechanical properties } \\
\hline \multirow[t]{2}{*}{ No } & \multicolumn{3}{|l|}{ Dimension } & \multirow{2}{*}{$\begin{array}{l}F_{0.5} \\
(\mathrm{kN})\end{array}$} & \multirow{2}{*}{$\begin{array}{l}F_{\mathrm{m}} \\
(\mathrm{kN})\end{array}$} & \multirow{2}{*}{$\begin{array}{l}R_{0.5} \\
(\mathrm{MPa})\end{array}$} & \multirow{2}{*}{$\begin{array}{l}R_{\mathrm{m}} \\
(\mathrm{MPa})\end{array}$} & \multirow{2}{*}{$\begin{array}{l}L_{\mathrm{u}} \\
(\mathrm{mm})\end{array}$} & \multirow{2}{*}{$\begin{array}{l}A_{5} \\
(\%)\end{array}$} & \multirow[t]{2}{*}{ Remarks } \\
\hline & $a_{0} \times b_{0}(\mathrm{~mm})$ & $L_{0}(\mathrm{~mm})$ & $S_{0}\left(\mathrm{~mm}^{2}\right)$ & & & & & & & \\
\hline $4 \mathrm{~A}$ & $17.1 \times 25.3$ & 120 & 432.6 & 239.6 & 275.3 & 553.9 & 636.4 & 145.7 & 21.4 & Transversal to the pipes axis \\
\hline $4 \mathrm{~B}$ & $17.1 \times 25.2$ & 120 & 430.9 & 243.2 & 273.3 & 564.5 & 634.3 & 144.7 & 20.6 & \\
\hline $5 \mathrm{~A}$ & $17.1 \times 25.0$ & 120 & 427.5 & 258.3 & 279.6 & 604.1 & 654.0 & 147.4 & 22.8 & Parallel to the pipes axis \\
\hline $5 \mathrm{~B}$ & $17.15 \times 24.9$ & 120 & 427.0 & 259.6 & 279.1 & 607.8 & 653.5 & 146.9 & 22.4 & \\
\hline
\end{tabular}

Table 3 The mechanical properties of API 5L X70 (L485M) steel, impact energy

\begin{tabular}{|c|c|c|c|c|c|c|c|c|c|c|c|c|c|c|c|c|c|}
\hline \multicolumn{3}{|c|}{ Specimen } & \multicolumn{15}{|c|}{ Impact energy $(\mathrm{J}) /$ toughness $\left(\mathrm{J} / \mathrm{cm}^{2}\right)$} \\
\hline \multirow[t]{2}{*}{ No } & \multicolumn{2}{|l|}{ Dimension } & \multicolumn{15}{|c|}{ Temperature } \\
\hline & $a_{0} \times b_{0}(\mathrm{~mm})$ & $S_{0}\left(\mathrm{~mm}^{2}\right)$ & +20 & & & 0 & & & -10 & & & -20 & & & -40 & & \\
\hline PM & $8.0 \times 10.0$ & 80.0 & $\begin{array}{l}246 \\
307.5\end{array}$ & $\begin{array}{l}242 \\
302.5\end{array}$ & $\begin{array}{l}244 \\
305\end{array}$ & $\begin{array}{l}238 \\
297.5\end{array}$ & $\begin{array}{l}234 \\
292.5\end{array}$ & $\begin{array}{l}230 \\
287.5\end{array}$ & $\begin{array}{l}228 \\
285.0\end{array}$ & $\begin{array}{l}184 \\
230.0\end{array}$ & $\begin{array}{l}236 \\
295.0\end{array}$ & $\begin{array}{l}238 \\
297.5\end{array}$ & $\begin{array}{l}236 \\
295.0\end{array}$ & $\begin{array}{l}240 \\
300.0\end{array}$ & $\begin{array}{l}238 \\
297.5\end{array}$ & $\begin{array}{l}224 \\
280.0\end{array}$ & $\begin{array}{l}226 \\
282.5\end{array}$ \\
\hline
\end{tabular}

Table 4 Welding parameters for girth welded joints

\begin{tabular}{|c|c|c|c|c|c|c|c|c|}
\hline Run no. & Filler material & $\begin{array}{l}\text { Size of filler } \\
\text { material }(\mathrm{mm})\end{array}$ & Current (A) & Voltage (V) & $\begin{array}{l}\text { Type of cur- } \\
\text { rent/polarity }\end{array}$ & $\begin{array}{l}\text { Wire feed } \\
\text { speed }(\mathrm{m} / \\
\text { min) }\end{array}$ & $\begin{array}{l}\text { Travel speed } \\
(\mathrm{cm} / \mathrm{min})\end{array}$ & Heat input $^{\mathrm{a}}(\mathrm{kJ} / \mathrm{mm})$ \\
\hline \multicolumn{9}{|c|}{ MMA welding (111), Pipeliner 6P+, FOX EV65 } \\
\hline 1 & \multirow[t]{2}{*}{ Pipeliner 6P+ } & \multirow[t]{3}{*}{$\varnothing 3.2$} & 110 & 30 & \multirow[t]{2}{*}{$\mathrm{DC} /-$} & - & 12 & 1.32 \\
\hline 2 & & & 115 & 26 & & - & 20 & 0.72 \\
\hline $3-n$ & FOX EV65 & & $110-125$ & $23-25$ & $\mathrm{DC} /+$ & - & 15 & $0.81-1.00$ \\
\hline \multicolumn{9}{|c|}{ MMA welding (111), Pipeliner 6P+, FOX EV85 } \\
\hline 1 & \multirow[t]{2}{*}{ Pipeliner 6P+ } & \multirow[t]{3}{*}{$\varnothing 3.2$} & 110 & 30 & \multirow[t]{2}{*}{$\mathrm{DC} /-$} & - & 12 & 1.32 \\
\hline 2 & & & 115 & 26 & & - & 20 & 0.72 \\
\hline $3-n$ & FOX EV65 & & $120-135$ & $22.5-23.5$ & $\mathrm{DC} /+$ & - & $5.7-7.2$ & $1.80-2.67$ \\
\hline \multicolumn{9}{|c|}{ MAG welding (135), Carbofil MnMo } \\
\hline 1 & \multirow[t]{3}{*}{ Carbofil MnMo } & \multirow[t]{3}{*}{$\varnothing 1.2$} & 100 & 18.4 & \multirow[t]{3}{*}{$\mathrm{DC}+$} & 2.5 & 24 & 0.37 \\
\hline 2 & & & 137 & 18.7 & & 3.7 & 26 & 0.47 \\
\hline $3-n$ & & & 147 & 18.4 & & 4.2 & 28 & 0.46 \\
\hline \multicolumn{9}{|c|}{ MAG welding (135), LMN MoNiVa } \\
\hline 1 & \multirow[t]{3}{*}{ LMN MoNiVa } & \multirow[t]{3}{*}{$\varnothing 1.2$} & 111 & 18.9 & \multirow[t]{3}{*}{$\mathrm{DC}+$} & 2.5 & 24 & 0.42 \\
\hline 2 & & & 146 & 19.1 & & 3.7 & 26 & 0.52 \\
\hline $5-n$ & & & 134 & 18.0 & & 4.2 & 28 & 0.41 \\
\hline
\end{tabular}

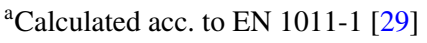


parameters were as follow: maximum welding current $400 \mathrm{~A}$ at $50 \%$ duty cycle and $320 \mathrm{~A}$ for $100 \%$, welding current range 25-400 A. The welding parameters for each girth welded joints are given in Table 4 .

\subsection{Mechanical properties}

After welding nondestructive (visual and radiographic tests) as well as destructive tests (metallographic examination, hardness test, bending test, transverse tensile test and impact tests) were carried out. The tensile tests according to the PN-EN ISO 4136:2013-05 [30] standard were carried out on transverse samples at room temperature. The tests were performed using an Instron 4210 tensile test machine. The impact tests were carried out at $+20^{\circ} \mathrm{C}$ and $-10{ }^{\circ} \mathrm{C}$ on the notched Charpy V-type specimens according to the requirements of the PN-EN ISO 148-1:2010 [31] and PN-EN ISO 9016:2013-05 [32] standards. Hardness measurements at loads of $10 \mathrm{~kg}(98.1 \mathrm{~N}), 5 \mathrm{~kg}(49.05 \mathrm{~N})$ as well as $1 \mathrm{~kg}$ $(9.81 \mathrm{~N})$ were carried out in acc. with the standards PN-EN ISO 9015-1:2011 [33] and PN-EN ISO 6507-1:2007 [34], with Vickers method for macroscopic cross-section, using an automatic hardness tester machine KB50 FA (Prüftechnik $\mathrm{GmbH}$ ). The bending tests according to the PN-EN ISO 5173: 2010/A1: 2012 standard [35] were also carried out.

\subsection{Microstructure}

To determine the effect of welding procedures on the microstructure of girth welded joints metallographic examination based on light microscopy and scanning electron microscopy were conducted. Macroscopic metallographic examination was carried out on the transverse samples etched with an Adler reagent in acc. with the requirements of the PN-EN ISO 17639: 2013-12E [36] standard. The microstructure was examined on the same sections after grinding, polishing and etching with $2 \%$ Nital. The investigations were performed by FEI Nova NanoSEM 450 scanning electron microscope (SEM) equipped with Circular Backscatter Detector (CBS) and Everhart-Thornley Detector (ETD).

\section{Results and discussion}

\subsection{Microstructure}

The microstructure of the base material, the API X70 steel, is shown in Fig. 2. It is composed of polygonal ferrite and granular bainite with the presence of a small amount of martensite-austenite constituent (MA) [7].

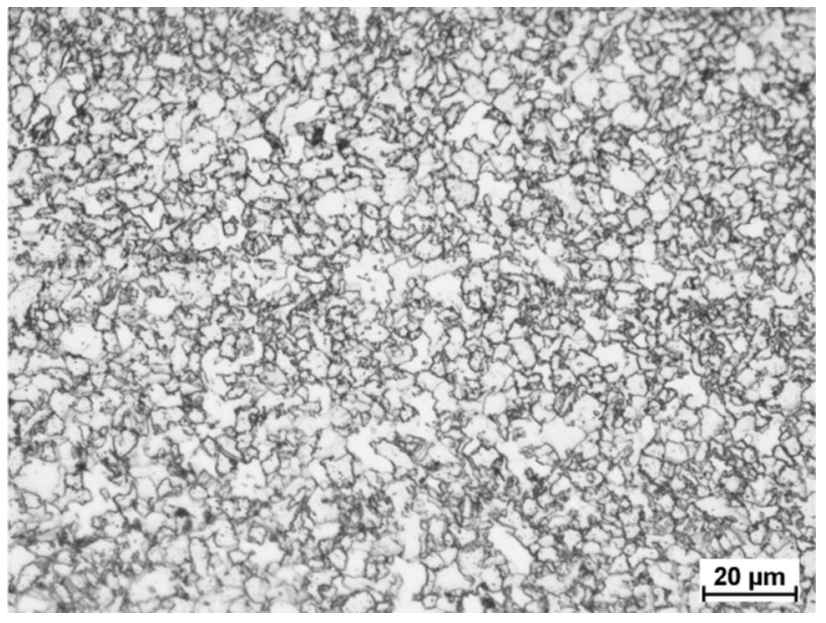

Fig. 2 Microstructure of steel API 5L X70 (L485), light microscope

\subsubsection{MMA welded joints}

The MMA girth welded joints were made with two different combinations of filler materials. Firstly, the root passes were made with covered electrode grade Pipeliner $6 \mathrm{P}+$ while the cap passes were made with covered electrode grade FOX EV 85. Secondly, the root passes were made with Pipeliner $6 \mathrm{P}+$ electrode while the cap passes were made with the filler FOX EV 65 material. The results of macroscopic examination of girth welded joints are presented in Fig. 3.

4.1.1.1 MMA welded joint made with FOX EV85 filler In the MMA girth welded joint made with FOX EV85 filler material for cap passes and Pipeliner 6P+ for root passes, from the microstructural point of view, the two different regions can be clearly distinguished (Figs. 4, 5). The root passes, formed by two weld beads, about $5 \mathrm{~mm}$ thick, were separated from the cap passes of the welded joints by a clear boundary.

Figure 4 shows the difference between root and cap passes made with various filler materials. In the root passes (bottom part) ferrite prevails with a grain size of several dozen micrometres. On the borders of ferrite grains, a second structural component, occurring as small islands of a few micrometres in diameter, can be distinguished. This may be either martensitic-austenitic (M/A) component [7, 37], bainite [7, 38] or fine perlite [38, 39] (Fig. 5a, b).

Taking into account the relatively too low hardness value for this steel (177 HV10) and the presented CTPc diagram (Fig. 6), it should be assumed that the second structural component, besides ferrite, is pearlite. This is not a typical pearlite with a characteristic lamellar structure, but pearlite known as "degenerated pearlite" or "ferrite-carbide aggregate" [10]. 
Fig. 3 Macroscopic examination of girth welded joints, a FOX EV 85+ Pipeliner 6P+ for root passes, b FOX EV 65+ Pipeliner $6 \mathrm{P}+$ for root passes

Fig. 4 Microstructure of MMA girth welded joint-weld metal: a root passes made with covered electrode Pipeliner $6 \mathrm{P}+$, b cap passes made with covered electrode FOX EV85, LM
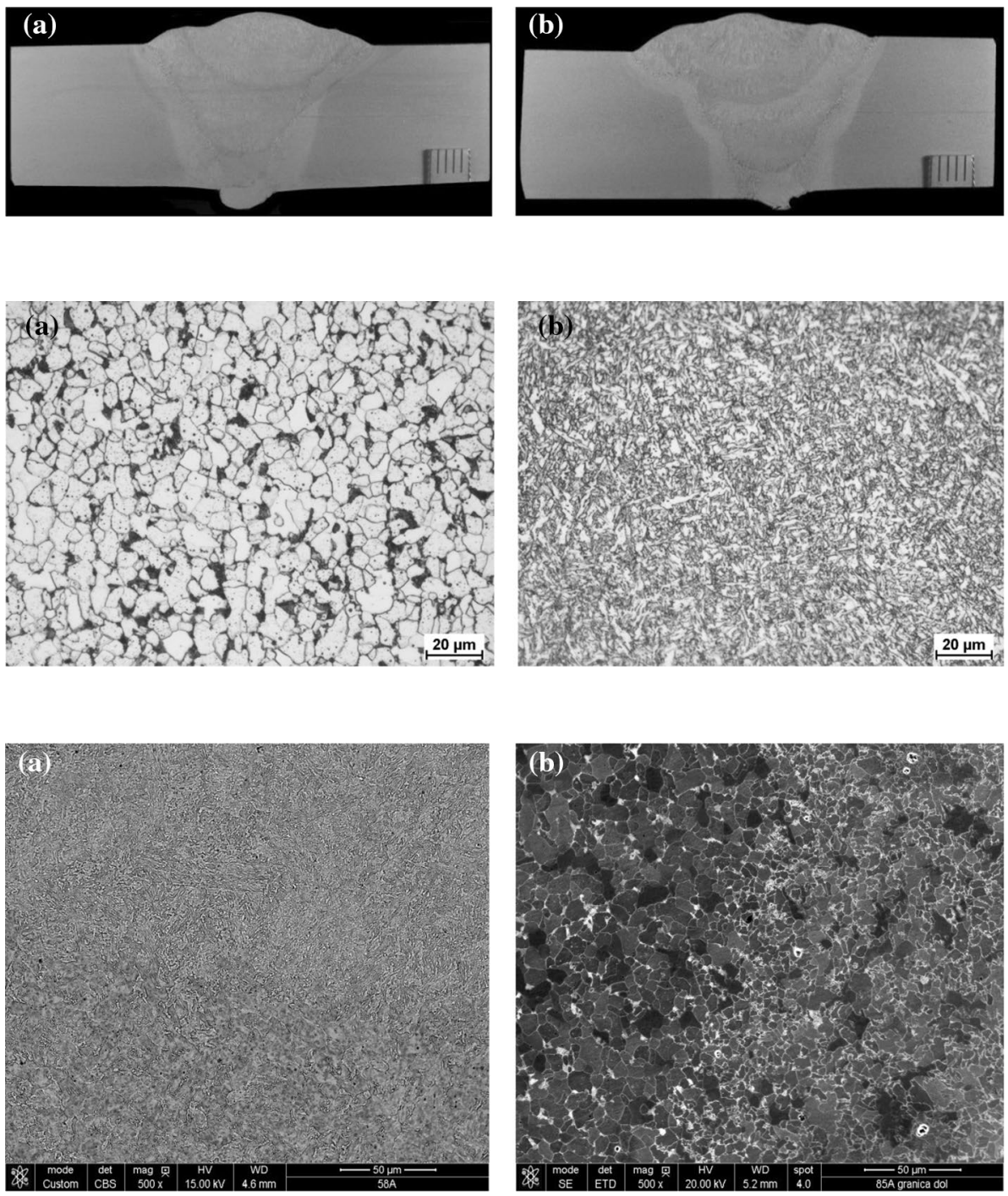

Fig. 5 Microstructure of weld metal (FOX EV85/Pipeliner $6 \mathrm{P}+$ )-boundary between root and cap passes made with various filler materials, a) SEMCBS (CBS - circular backscatter detector), b SEM-ETD (Everhart-Thornley detector)

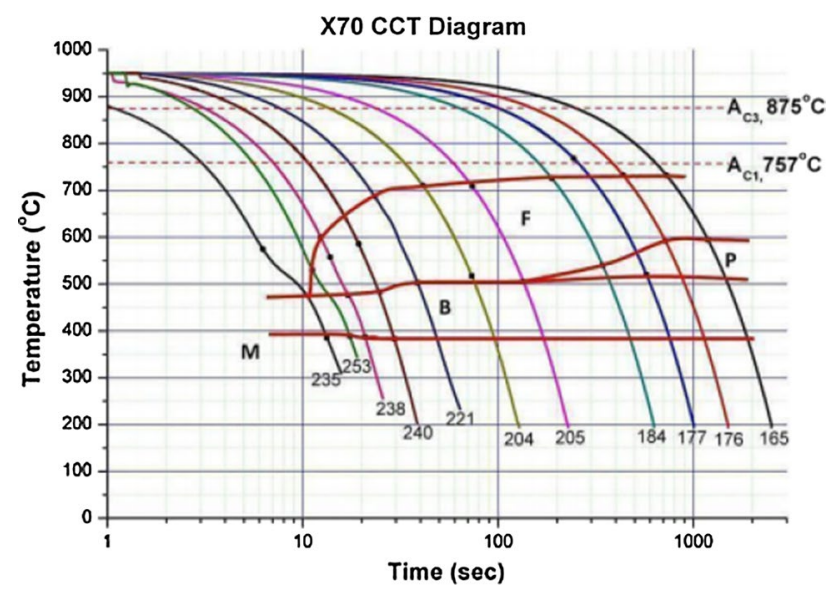

Fig. 6 API X70 CCT diagram showing the transformation lines identified [38]
Microstructure in the HAZ at a distance of about $1 \mathrm{~mm}$ from the fusion line is shown in Fig. 7a. Near to the polygonal ferrite, ferrite of different morphology, referred to as bainitic ferrite, which is characterized by irregular grain shape and often irregular boundaries can be observed (Fig. 7b). The hardness in this area was approximately HV170-the value close to the hardness of the base material and to the hardness of the API X70 steel [40].

The microstructure at the middle of the girth welded joint thickness, just above the root passes, is substantially different from the microstructure in the bottom part. This microstructure is shown in Fig. 8. While the microstructure in the HAZ is similar to that in the bottom region, the weld microstructure is different, as evidenced by the use of another filler material (FOX EV 85). This microstructure is a typical bainitic structure with ferrite strips and cementite inclusions [10, 40].

The microstructure in the proximity of the fusion line, a few millimetres above, changes not only in the weld 
Fig. 7 Microstructure of HAZ in the girth welded joint made with FOX EV85/Pipeliner $6 \mathrm{P}+$ - area near to the root passes $1 \mathrm{~mm}$ from the fusion line, a light microscopy, b SEM-ETD
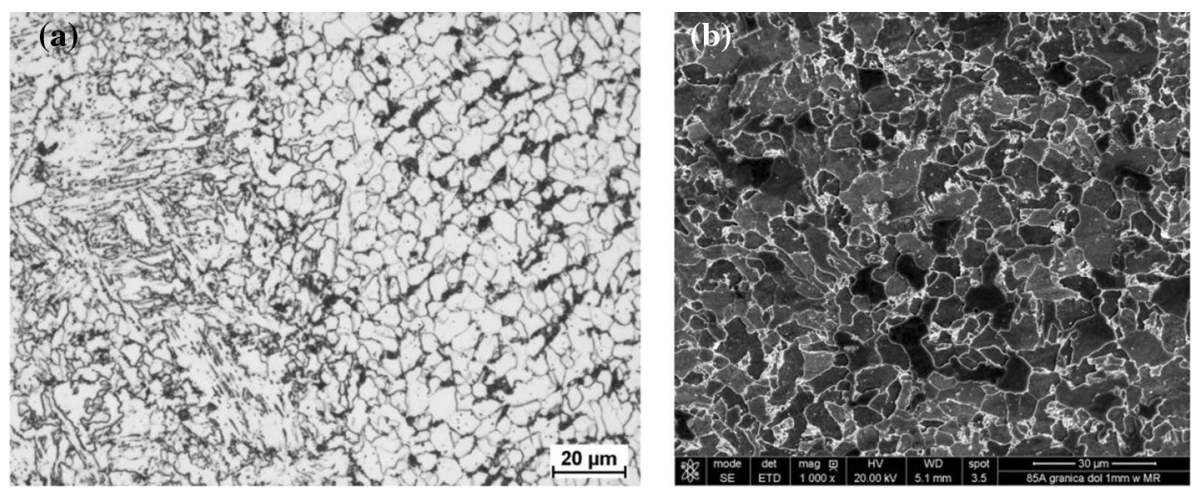

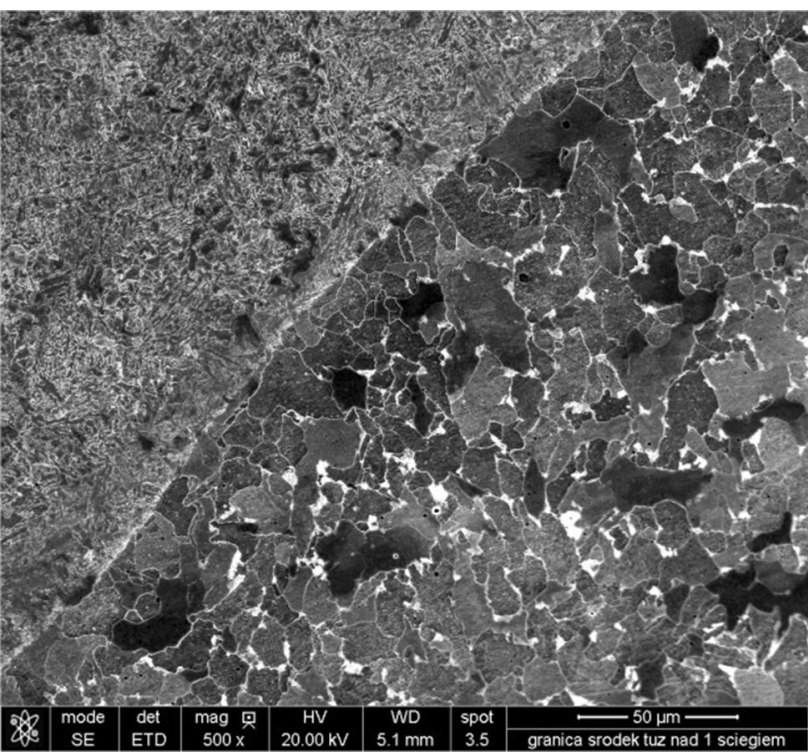

Fig. 8 Microstructure of HAZ and weld metal in the girth welded joint made with FOX EV85/Pipeliner 6P+-middle thickness of the welded joint, SEM-ETD

metal but also in the HAZ. The different microstructure in the HAZ at similar distances from the fusion line can be explained by the different thermal history of these areas. A typical microstructure of the area adjoining the fusion line in the middle of the welded joint is shown in Fig. 9a, b. Both micrographs represent the same area, however, the image in Fig. 9a was produced by secondary electrons (SEM-ETD technique) and the image in Fig. 9b was formed backscattered electrons (SEM-CBS technique). The bainitic structure was observed in both weld metal and HAZ, however, the HAZ was characterized by large primary austenite grains comparing to the weld metal area. Simultaneously, the boundaries of primary austenite grains were not explicitly defined. In addition, the M/A component was not observed in this area. The bainitic ferrite laths merge together and assumed complex shapes with irregular boundaries, however, the carbide precipitates within ferritic areas show the course of the original boundaries between bainitic ferrite laths. Such a structure resembles the structure observed in API X80 quenched from $950^{\circ} \mathrm{C}$ and subsequently tempered at $600{ }^{\circ} \mathrm{C}$ for $1 \mathrm{~h} \mathrm{[41]}$.

The microstructure near the face at the fusion line is also bainitic, but in this case the bainitic ferrite strips are more evident. Also, the boundaries of primary austenite grains are better recognizable, as shown in Fig. 10a. Small amount of ferrite was often observed on the primary austenite boundaries (Fig. 10b, top). Such a ferrite is often referred to as primary ferrite $[10,42]$.
Fig. 9 Microstructure in weld metal and HAZ in girth welded joint (FOX EV85/Pipeliner $6 \mathrm{P}+$ ) - area in the middle of the thickness of welded joint, $\mathbf{a}$ SEM-ETD, b SEM-CBS
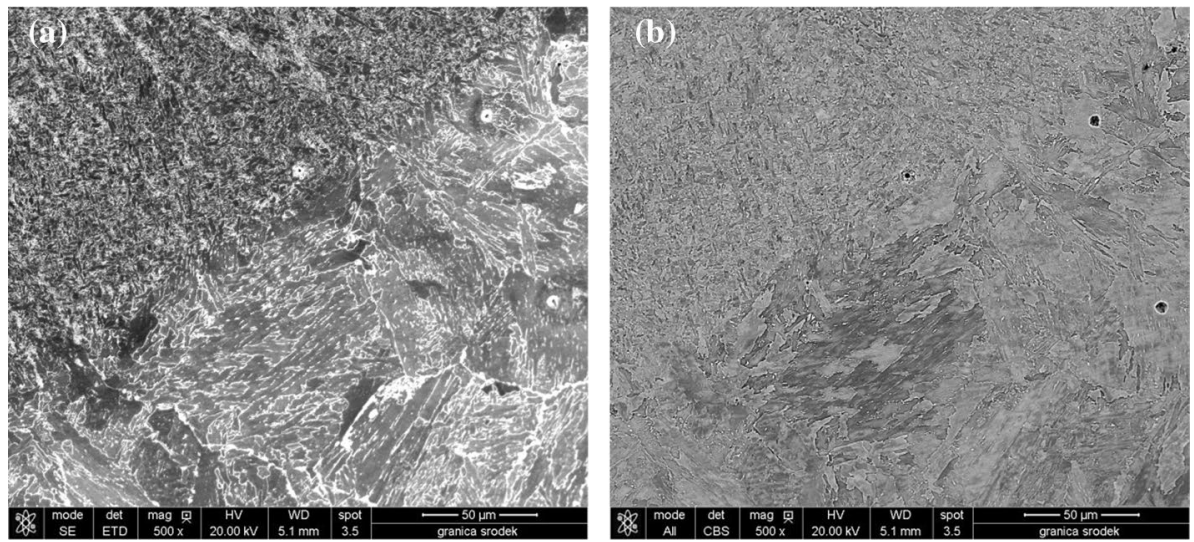
Changes in the microstructure near the fusion line at the face of the weld are reflected in the hardness values of these areas. The hardness in the welded joint near the face of the weld was approximately 283 HV1. This value may correspond to a microstructure composed of a mixture of martensite and lower bainite. The hardness in the HAZ was $229 \mathrm{HV} 1$, so taking into account the hardness values presented in Ref. [7], this value corresponds likely to the bainitic microstructure.

4.1.1.2 MMA welded joint made with FOX EV65 filler Also, in the MMA girth welded joint, made with other filler materials (FOX EV 65-cap passes, Pipeliner 6P+-root passes), the well-defined microstructural zones can be eas- ily distinguished in the weld metal at the light microscope scale (Fig. 11).

The microstructure of the HAZ was not homogeneous (Fig. 12) -near the fusion line at the root passes a coarsegrained microstructure was observed while closer to the cap passes a fine-grained zone could be distinguished. This is a typical microstructure observed in combinations of different types of structural steels. The microstructure is a mixture of different microstructural components, depending on the thermal history of the individual areas. It should be noted, that heat input (Table 4) was two times lower than for welded joint made with FOX EV85. Therefore, the lower grain size in the HAZ was observed.

According to Refs [10, 39], the weld microstructure may be composed of ferrite with various morphologies
Fig. 10 Microstructure of HAZ in the girth welded joint (FOX EV85/Pipeliner 6P+) -1 mm from the fusion line at the face of the weld, SEM-CBS, a lower magnification, $\mathbf{b}$ higher magnification
Fig. 11 Microstructure of weld metal in MMA girth welded joint, a root passes made with Pipeliner $6 \mathrm{P}+$, b cap passes made with FOX EV65, LM
Fig. 12 Microstructure of HAZ in the MMA girth welded joint: a near the root passes made with Pipeliner $6 \mathrm{P}+, \mathrm{b}$ near the cap passes made with FOX EV65, LM
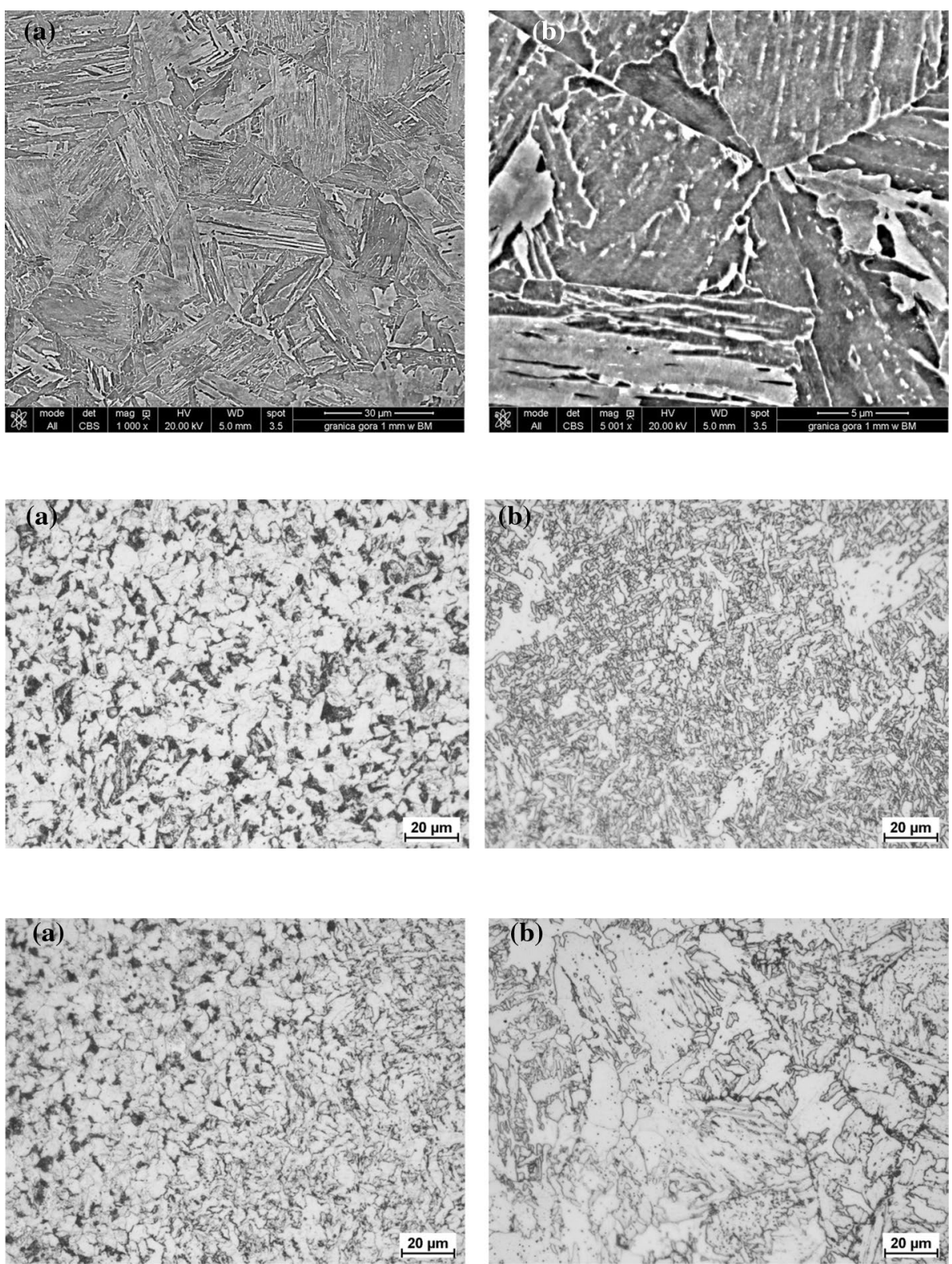
(polygonal, coniferous, acicular, ferrite at or around the borders of austenite grains, Widmanstätten ferrite, bainite ferrite), bainite (also with different morphology), perlite and martensite which usually occurs in the form of martensitic-austenitic islands (M/A). In the FOX EV65/Pipeliner $6 \mathrm{P}+$ welded joint, the weld metal microstructure was very similar to the weld microstructure in FOX EV85/Pipeliner $6 \mathrm{P}+$ welded joint. This resemblance pertains primarily to a different microstructure near the root and cap passes.

\subsubsection{MAG welded joints}

Two different welding technologies for the girth welded joints were applied in the presented research. The other one was the MAG process. The MAG girth welded joints with two different filler materials were produced. As first, the root passes and cap passes were made with wire LMN MoNiVa grade. Subsequently, girth welded joint was made with the wire Carbfil MnMo. Figure 13 shows the macrostructure of these welded joints. In both welded joints made by the MAG method the distinctive zones of different microstructure can be distinguished.

4.1.2.1 MAG welded joint made with LMN MoNiV The microstructure of the weld metal and HAZ of the welded joint made with the LMN MoNiV filler material for root and cap passes are shown in Figs. 14 and 15.

The microstructure of the weld metal constitutes fine bainite. The hardness of the weld metal is $320 \mathrm{HV} 1$, which well corresponds to the observed microstructure. In the $\mathrm{HAZ}$, it is possible to distinguish a coarse-grained area, typical of all steel weld metals, which continuously alters to the fine-grained area. The microstructure near the fusion line is similar, but not uniform, throughout the joint thickness. The microstructure observed by SEM is shown in Fig. 16a (root passes) and 16b (cap passes). Near the weld face, both in the weld metal itself and adjacent HAZ, ferrite has acicular morphology (Fig. 16b), however, in the vicinity of the root passes ferrite areas take irregular shapes, while the microstructure of the weld has been preserved (Fig. 16b). A
Fig. 13 Macroscopic examination of MAG girth welded joints, a LMN MoNiVa, b Carbfil MnMo
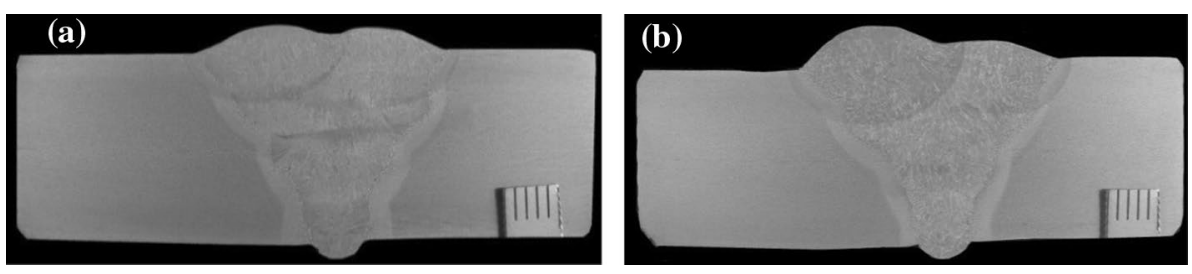

Fig. 14 Microstructure of weld metal in the MAG girth welded joint made with LMN MoNiVa, a root passes, $\mathbf{b}$ cap passes, LM

Fig. 15 Microstructure of HAZ in the MAG girth welded joint made with LMN MoNiVa, a root passes, $\mathbf{b}$ cap passes, LM
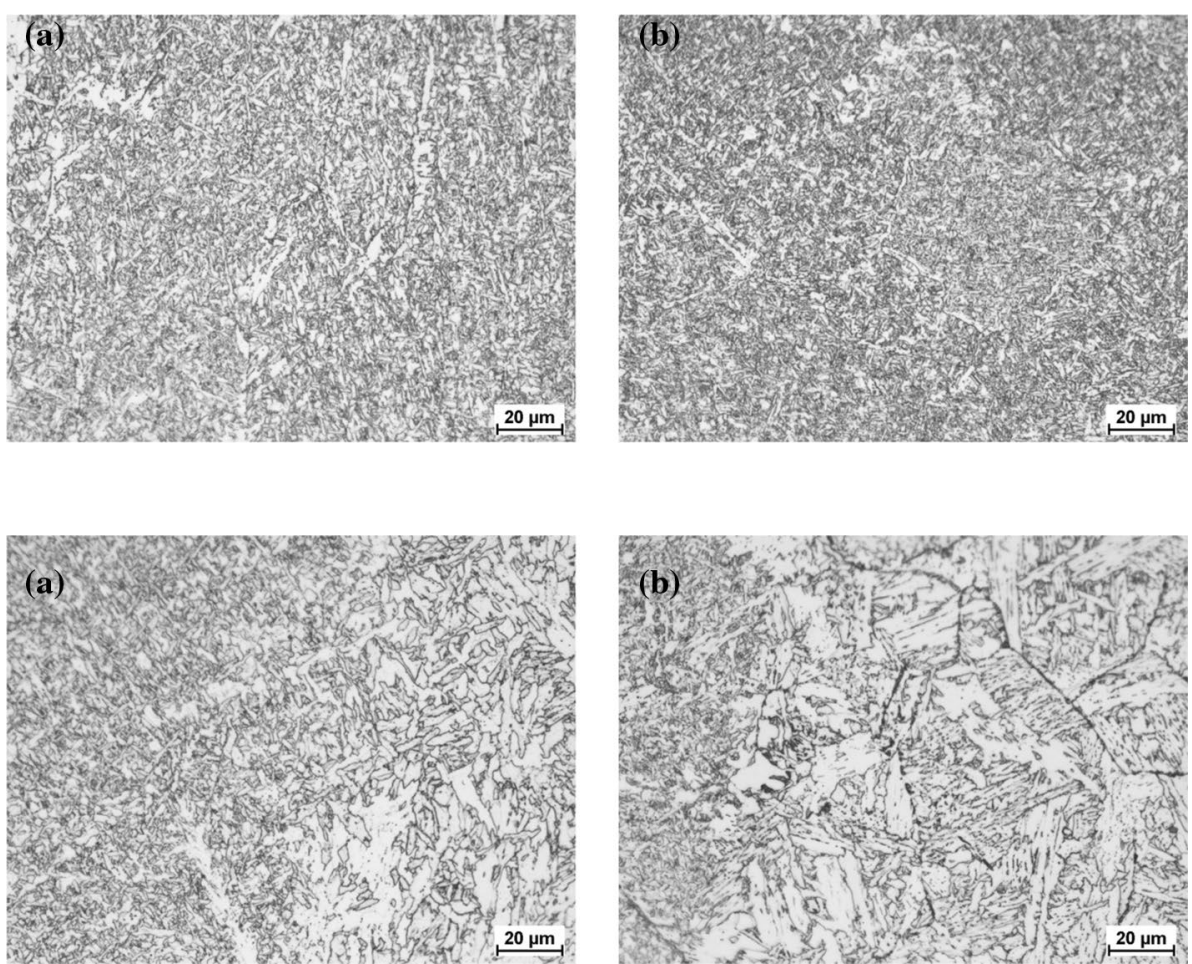
Fig. 16 Microstructure of weld metal and HAZ of MAG girth welded joint made with LMN MoNiVa, a weld metal on the right in the root passes, SEMCBS, $\mathbf{b}$ weld metal on the right in the cap passes, SEM-CBS, c weld metal on the right in the cap passes, SEM-ETD
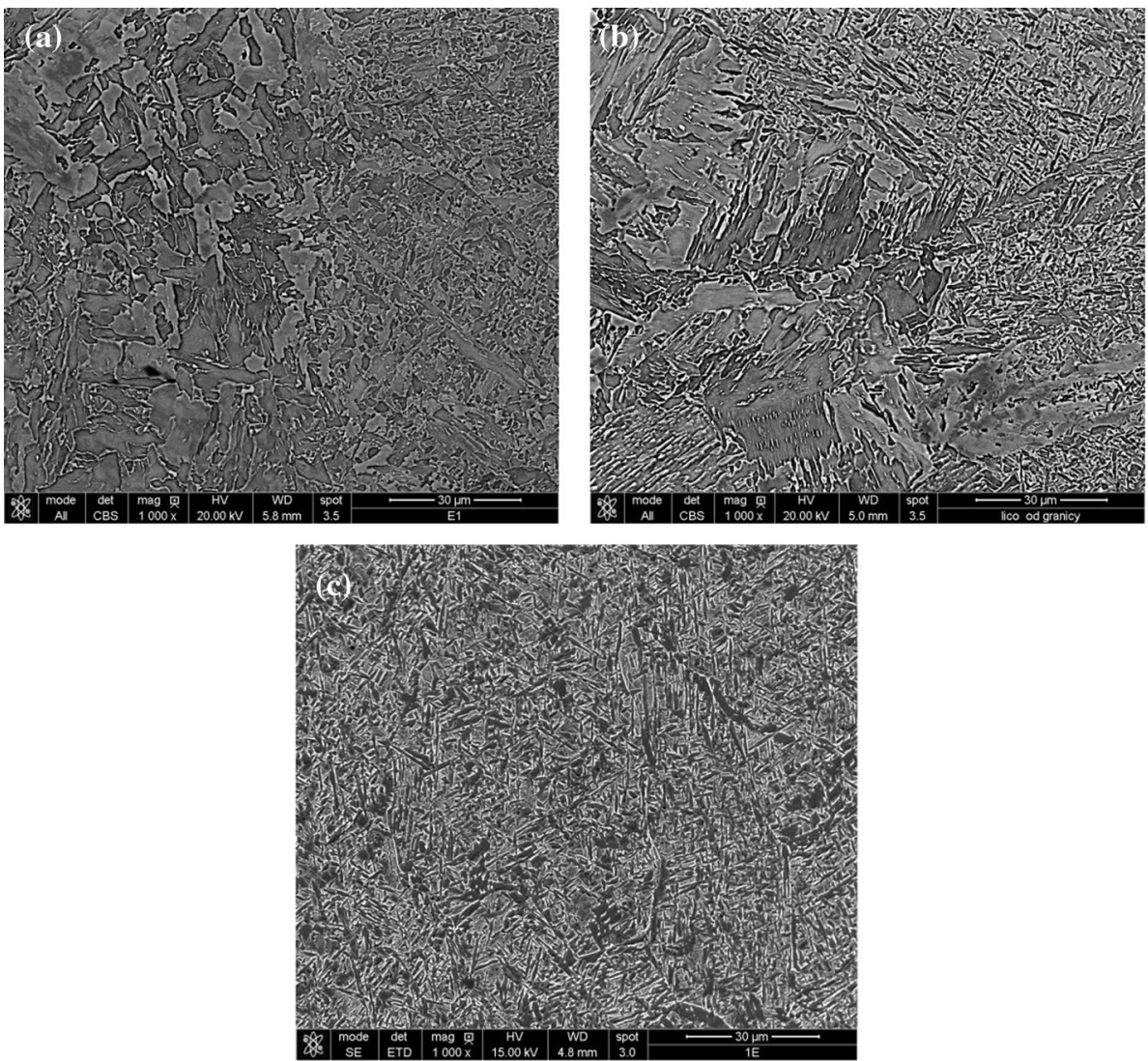

typical microstructure of the weld metal in its central part is shown in Fig. 16c. Apart from acicular ferrite, ferrite in the form of a continuous phase nucleating on the original austenite boundaries can be distinguished.

The microstructure of the HAZ does not show any significant changes across the thickness of the welded joint. The evolution of the HAZ microstructure in the root passes area at different distances from the fusion line (2, 4 and $7 \mathrm{~mm}$ ) are shown in Fig. 17a-c, respectively. Micrographs clearly indicate the vanishing of acicular ferrite morphology with the increasing distance from the fusion line. The fine-grained form was found at a distance of just $7 \mathrm{~mm}$ from the fusion line (Fig. 17c). Simultaneously, changes in the morphology of the precipitated carbides occur in the microstructure, which are visible at higher magnifications. There are very fine spherical precipitates in some grains. In other grains, the cementite takes the form of twisted lamella that is often referred to as the degenerate perlite [10] - Fig. 17d.

\subsubsection{MAG welded joint made with Carbofil MnMo The} microstructure of the weld metal and the HAZ in MAG girth welded joints made with Carbofil MnMo filler material are shown in Figs. 18 and 19. Compared to the MAG welded joint made with LMN MoNiVa filler material, the microstructure is characterized by a larger primary austenite grain. Moreover, on the primary boundaries the ferrite appears as a continuous phase or the Widmanstätten ferrite with plates growing into the grain interior. In the heat-affected zone, the microstructure changes continuously from the coarsethrough fine-grained structure to the structure of the base material (Fig. 20a).

The microstructure of the areas adjacent to the fusion line is shown in Fig. 20a (area near the root passes) and 20b (area near the cap passes). The microstructures in the weld metal and the HAZ are similar. However, the appearance of microstructure in HAZ is rapidly changing with the distance from the fusion line. These changes are shown in Fig. 20c-e that are characteristic for areas $0.5,1$, and $1.5 \mathrm{~mm}$ apart from the fusion line. The difference in the ferrite morphology is apparent.

\subsection{Mechanical properties}

To characterise the mechanical properties of the girth welded joints produced by MMA and MAG welding processes, hardness maps, hardness distribution as well as tensile, bend and impact tests were performed. Figure 21 shows hardness maps constructed from a grid of hardness indents (ca. 2250 in total) applied on the welded joint cross sections. The applied load was $5 \mathrm{~kg}$ (HV5). Clearly, the largest variation in hardness occurs in the through-thickness direction. It should be noted, however, that for the MMA welded joints 
Fig. 17 Microstructure of HAZ in the MAG girth welded joint made with LMN MoNiVa filler material, area near the root passes, a $2 \mathrm{~mm}$ from the fusion line, SEM-CBS, b $4 \mathrm{~mm}$ from the fusion line, SEM-CBS, c $7 \mathrm{~mm}$ from the fusion line, SEM-CBS, d $6 \mathrm{~mm}$ from the fusion line, SEM-CBS

Fig. 18 Microstructure of weld metal in the MAG girth welded joint made with Carbofil MnMo, a root passes, $\mathbf{b}$ cap passes, LM

Fig. 19 Microstructure of HAZ in the MAG girth welded joint made with Carbofil MnMo, a neat the root passes, $\mathbf{b}$ near the cap passes, LM
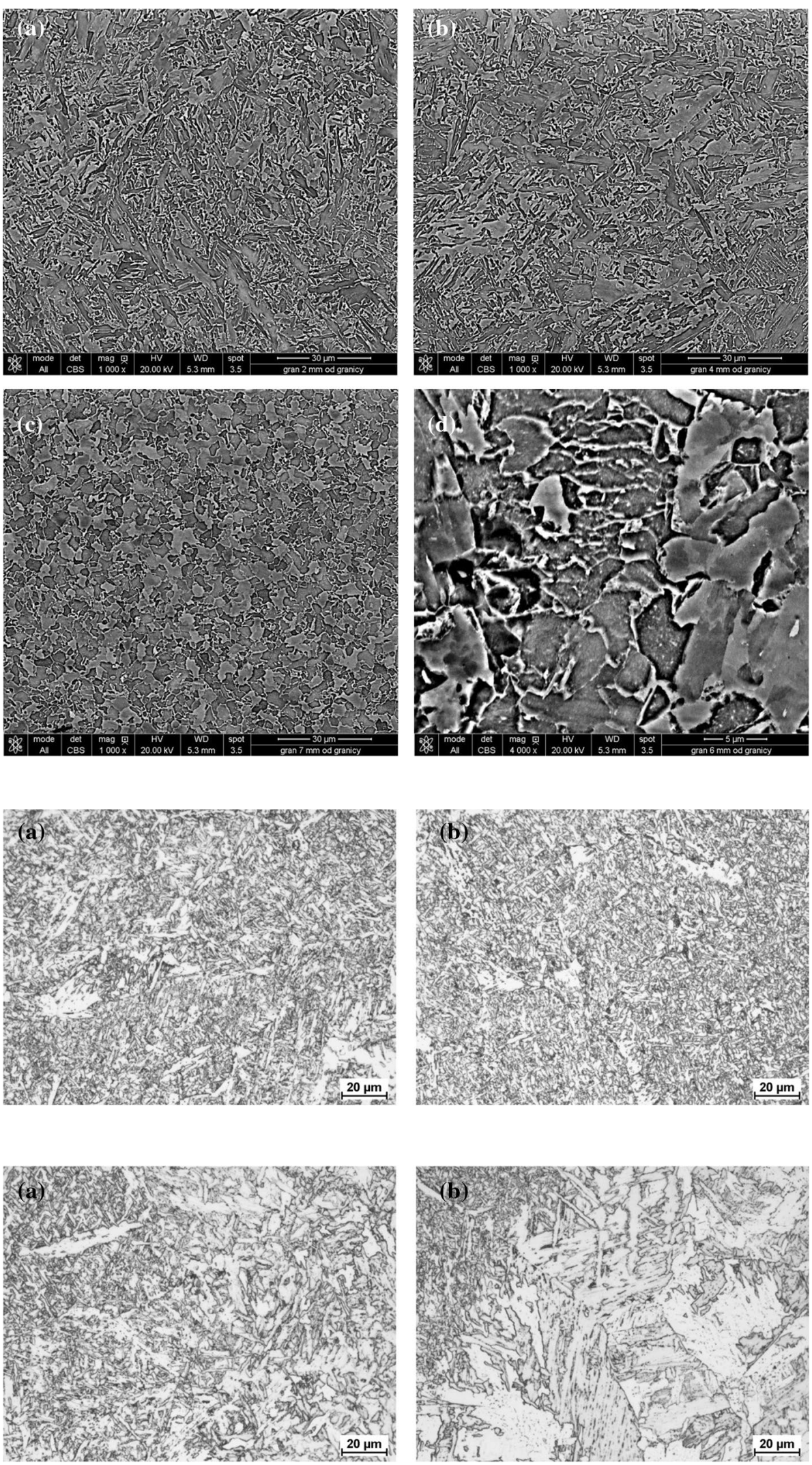
Fig. 20 Microstructure of HAZ in the MAG girth welded joint made with Carbofil MnMo, a area near to the root passes, SEM-CBS, $\mathbf{b}$ area near to the cap passes, SEM-CBS, c area near to the root passes $0.5 \mathrm{~mm}$ from the fusion line, SEMCBS, $\mathbf{d}$ area near to the root passes $1.0 \mathrm{~mm}$ from the fusion line, SEM-CBS, e area near to the root passes $1.5 \mathrm{~mm}$ from the fusion line, SEM-CBS
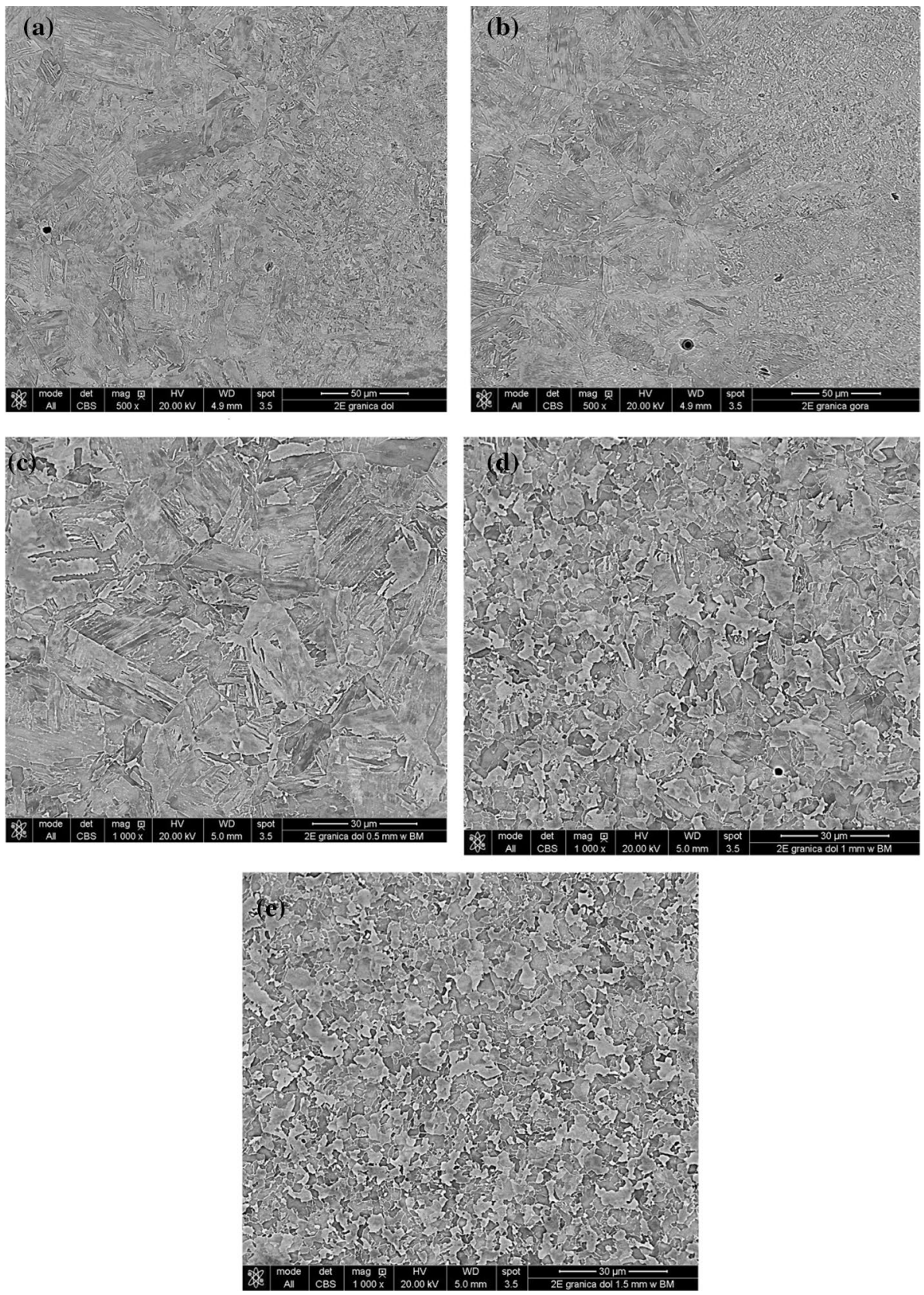

three different filler materials were used: Pipeliner $6 \mathrm{P}+$ for root passes as well as FOX EV65 and FOX EV85 for cap passes. The results reveal that the hardness in the root is much lower than in cap passes (Fig. 21b).

The difference in the highest hardness values for different filler materials in the cap passes is clearly demonstrated in Fig. 21. It results from the different mechanical properties of filler materials as well as from the thermal cycles that affected the material during welding. According to the PN-EN ISO 15653:2010 standard [42] the hardness may be used to estimate the yield and tensile strengths $\left(R_{\mathrm{e}}\right.$ and $\left.R_{\mathrm{m}}\right)$. The following equations: $R_{\mathrm{e}}=2.35 \mathrm{HV} 10+62$ and $R_{\mathrm{m}}=3.0 \mathrm{HV} 10+22.1$, suggested for steel weld metal (in MPa) can be adopted for the calculation. The results of mechanical tests for MMA girth welded joints are presented in Table 5. Mechanical properties of the MMA filler materials are presented in Table 6 . The results in Table 6 and Fig. 22 show the good agreement between presented values. The differences between calculation and measurements result from the nature of welding process and thermal history of each welding pass. It should be noted that the hardness distribution corresponds with the microstructure of particular parts of welded joints and reflects their heterogeneity.

It may be observed that there is a better agreement between experimental hardness values, and values calculated from $\mathrm{Rm}$, compared to values calculated from Re. This is 

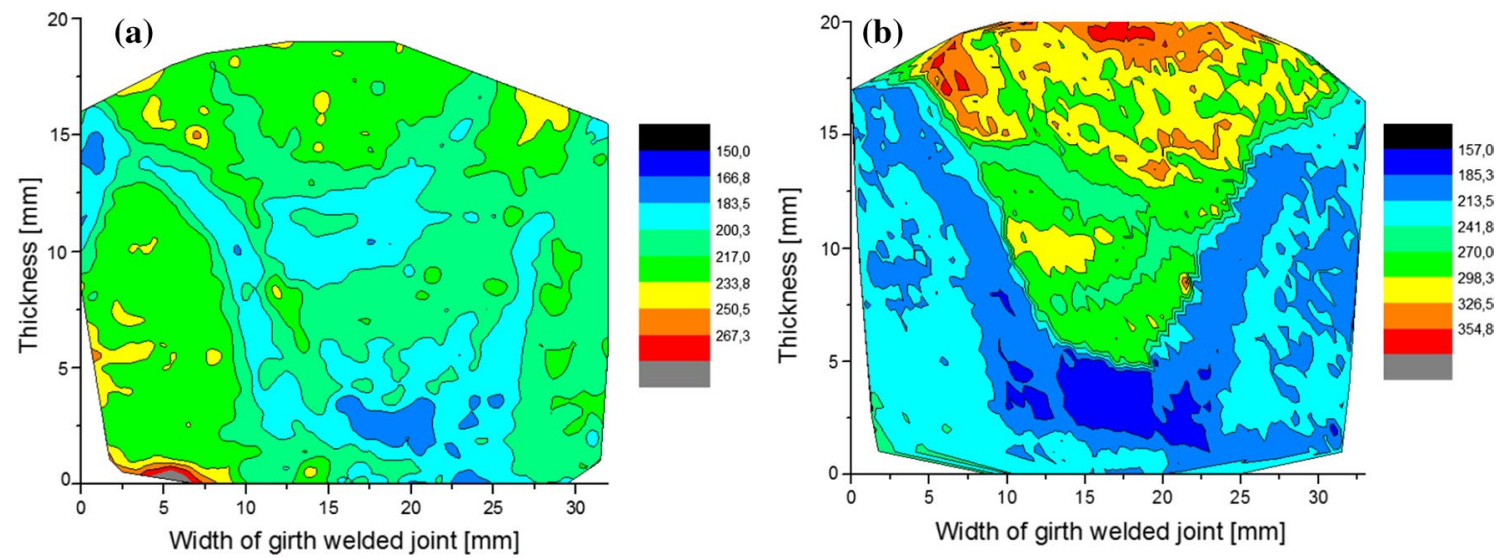

Fig. 21 Hardness map (HV5) of MMA girth welded joints: a FOX EV65+ Pipeliner 6P+, b FOX EV85 + Pipeliner 6P+

Table 5 Mechanical properties of girth welded joints, MMA welding process

\begin{tabular}{|c|c|c|c|c|c|c|c|c|c|c|c|}
\hline \multicolumn{3}{|l|}{ Specimen } & \multicolumn{9}{|c|}{ Mechanical properties } \\
\hline \multirow[t]{2}{*}{ No } & \multicolumn{2}{|l|}{ Dimension } & \multirow[t]{2}{*}{$\overline{F_{\mathrm{m}}(\mathrm{kN})}$} & \multirow[t]{2}{*}{$R_{\mathrm{m}}(\mathrm{MPa})$} & \multirow[t]{2}{*}{ Bend angle $\left(^{\circ}\right)$} & \multicolumn{6}{|c|}{ Impact energy $(\mathrm{J}) /$ toughness $\left(\mathrm{J} / \mathrm{cm}^{2}\right)$} \\
\hline & $a_{0} \times b_{0}(\mathrm{~mm})$ & $S_{0}\left(\mathrm{~mm}^{2}\right)$ & & & & $+20^{\circ} \mathrm{C}$ & & & $-10^{\circ} \mathrm{C}$ & & \\
\hline \multicolumn{12}{|l|}{ FOX EV65 } \\
\hline $65 \mathrm{~A} / \mathrm{R} / 1$ & $16.4 \times 25.2$ & 413.3 & 262.0 & $634.1^{*}$ & & & & & & & \\
\hline $65 \mathrm{~A} / \mathrm{R} / 2$ & $16.7 \times 25.1$ & 419.2 & 265.6 & $633.7^{*}$ & & & & & & & \\
\hline $65 \mathrm{~A} / \mathrm{FBB}$ & $16.3 \times 27.1$ & 441.7 & & & 180 & & & & & & \\
\hline $65 \mathrm{~A} / \mathrm{RBB} / 1$ & $16.4 \times 26.8$ & 439.5 & & & 180 & & & & & & \\
\hline $65 \mathrm{~A} / \mathrm{RBB} / 2$ & $16.2 \times 26.5$ & 429.3 & & & 180 & & & & & & \\
\hline 65/VWT & $8.0 \times 10.0$ & 80.0 & & & & $\begin{array}{l}152 \\
190.0\end{array}$ & $\begin{array}{l}154 \\
192.5\end{array}$ & $\begin{array}{l}146 \\
182.5\end{array}$ & $\begin{array}{l}130 \\
162.5\end{array}$ & $\begin{array}{l}124 \\
155.0\end{array}$ & $\begin{array}{l}110 \\
137.5\end{array}$ \\
\hline $65 / \mathrm{VHT}$ & $8.0 \times 10.0$ & 80.0 & & & & $\begin{array}{l}170 \\
212.5\end{array}$ & $\begin{array}{l}174 \\
217.5\end{array}$ & $\begin{array}{l}178 \\
222.5\end{array}$ & $\begin{array}{l}128 \\
160.0\end{array}$ & $\begin{array}{l}92 \\
115.0\end{array}$ & $\begin{array}{l}150 \\
187.5\end{array}$ \\
\hline $65 /$ VHT 2 & $8.0 \times 10.0$ & 80.0 & & & & $\begin{array}{l}230 \\
287.5\end{array}$ & $\begin{array}{l}154 \\
192.5\end{array}$ & $\begin{array}{l}224 \\
280.0\end{array}$ & $\begin{array}{l}188 \\
235.0\end{array}$ & $\begin{array}{l}166 \\
207.5\end{array}$ & $\begin{array}{l}186 \\
232.5\end{array}$ \\
\hline 65/VHT 5 & $8.0 \times 10.0$ & 80.0 & & & & $\begin{array}{l}242 \\
302.5\end{array}$ & $\begin{array}{l}252 \\
315.0\end{array}$ & $\begin{array}{l}228 \\
285.0\end{array}$ & $\begin{array}{l}220 \\
275.0\end{array}$ & $\begin{array}{l}242 \\
302.5\end{array}$ & $\begin{array}{l}230 \\
287.5\end{array}$ \\
\hline \multicolumn{12}{|l|}{ FOX EV85 } \\
\hline $85 \mathrm{~A} / \mathrm{R} / 1$ & $16.8 \times 25.0$ & 420.0 & 275.7 & $656.5 * *$ & & & & & & & \\
\hline $85 \mathrm{~A} / \mathrm{R} / 2$ & $16.5 \times 25.1$ & 414.2 & 279.6 & $675.0 * *$ & & & & & & & \\
\hline $85 \mathrm{~A} / \mathrm{FBB}$ & $16.8 \times 26.0$ & 436.8 & & & 180 & & & & & & \\
\hline $85 \mathrm{~A} / \mathrm{RBB} / 1$ & $16.4 \times 24.5$ & 401.8 & & & 180 & & & & & & \\
\hline $85 \mathrm{~A} / \mathrm{RBB} / 2$ & $16.4 \times 25.4$ & 416.6 & & & 180 & & & & & & \\
\hline 65/VWT & $8.0 \times 10.0$ & 80.0 & & & & $\begin{array}{l}120 \\
150.0\end{array}$ & $\begin{array}{l}112 \\
140.0\end{array}$ & $\begin{array}{l}120 \\
150.0\end{array}$ & $\begin{array}{l}86 \\
107.5\end{array}$ & $\begin{array}{l}102 \\
127.5\end{array}$ & $\begin{array}{l}86 \\
107.5\end{array}$ \\
\hline $65 / \mathrm{VHT}$ & $8.0 \times 10.0$ & 80.0 & & & & $\begin{array}{l}100 \\
125.0\end{array}$ & $\begin{array}{l}156 \\
195.0\end{array}$ & $\begin{array}{l}160 \\
200.0\end{array}$ & $\begin{array}{l}210 \\
262.5\end{array}$ & $\begin{array}{l}104 \\
130.0\end{array}$ & $\begin{array}{l}82 \\
102.5\end{array}$ \\
\hline 65/VHT 2 & $8.0 \times 10.0$ & 80.0 & & & & $\begin{array}{l}216 \\
270.0\end{array}$ & $\begin{array}{l}224 \\
280.0\end{array}$ & $\begin{array}{l}216 \\
270.0\end{array}$ & $\begin{array}{l}214 \\
267.5\end{array}$ & $\begin{array}{l}88 \\
110.0\end{array}$ & $\begin{array}{l}122 \\
152.5\end{array}$ \\
\hline 65/VHT 5 & $8.0 \times 10.0$ & 80.0 & & & & $\begin{array}{l}222 \\
277.5\end{array}$ & $\begin{array}{l}218 \\
272.5\end{array}$ & $\begin{array}{l}222 \\
277.5\end{array}$ & $\begin{array}{l}200 \\
250.0\end{array}$ & $\begin{array}{l}206 \\
257.5\end{array}$ & $\begin{array}{l}198 \\
247.5\end{array}$ \\
\hline
\end{tabular}

Identifications of test specimens: R/1 and R/2, specimens for tensile tests; FBB, face bend test of the butt welds; RBB, root bend test of the butt welds; VWT, impact test: V, Charpy-V notch; W, notch in weld metal; T, notch through thickness; VHT, impact test: Charpy-V notch; H, notch in heat-affected zone; T, notch through thickness; VHT 2, impact test: Charpy-V notch; H, notch in heat-affected zone; T, notch through thickness; 2, 5, $2 \mathrm{~mm}$ and $5 \mathrm{~mm}$ from the fusion line

Tensile tests: *rupture in the welded metal, **rupture out of the welded metal, bend test: $d=4 \mathrm{~g}, d=60 \mathrm{~mm}$ 
Table 6 Mechanical properties of MMA filler material [43, 44]

\begin{tabular}{lllll}
\hline $\begin{array}{l}\text { Filler mate- } \\
\text { rial }\end{array}$ & $R_{\mathrm{m}}(\mathrm{MPa})$ & $\begin{array}{l}\mathrm{HV} 10 \text { from } \\
R_{\mathrm{m}}\end{array}$ & $R_{\mathrm{e}}(\mathrm{MPa})$ & $\mathrm{HV} 10$ from $R_{\mathrm{e}}$ \\
\hline FOX EV85 & 927.6 & 301,8 & 870.7 & 344.1 \\
FOX EV65 & 625.6 & 201.2 & 559.5 & 211.7 \\
Pipeliner 6P+ & 548.7 & 175.5 & 465.0 & 171.5 \\
\hline
\end{tabular}

logical since it is known that hardness is more closely related to $\mathrm{Rm}$ than to Re according to the original works by Tabor [44]. Less scatter is observed in HV-Rm diagrams, compared to HV-Re diagrams.

It should be noted, that higher impact energy for MMA girth welded joints made with FOX EV65 filler can be observed (Table 2). It can be caused by the following reason: the heat input during MMA welding with FOX EV65 is much lower than for FOX EV85 (see Table 4), thus the cooling time $t_{8 / 5}$ is lower and finally the impact energy can be higher [45-47]. Simultaneously hardness (Fig. 22) is a little bit lower at HAZ and much lower in the weld metal.

The same grade of filler material was applied for the MAG welded joints. Therefore, only one thermal cycle of welding processes influenced the hardness distribution.
The hardness maps for MAG joints are shown in Fig. 23. The mechanical properties of MAG joints are presented in Table 7. Moreover, the mechanical properties of weld metals and calculated hardness values according to the PN-EN ISO 15653:2010 standard are presented in Table 8. The calculation of hardness strongly matches the experimental data (Fig. 24). However, the real welding process associated with annealing phenomena makes the experimental hardness values lower than calculated.

The results of the hardness distribution of MMA and MAG girth welded joints confirmed the microstructural evaluation presented in the previous section. The thermal cycles that high strength low alloy and carbon API X70 steel experience during welding inevitably affect microstructure and mechanical properties of the MMA and MAG welded joints. It is generally agreed that the adopted welding filler materials influence on mechanical properties of weld metals. For MMA welding with FOX EV65 as well as FOX EV85 the microstructure of weld metal is similar and is composed of ferrite with various morphologies, bainite, perlite and martensite which usually occurs in the form of martensitic-austenitic islands (M/A). However, the chemical composition of weld metals [21, 23] influences on hardness and strength of welded joints. For FOX EV85 higher strength
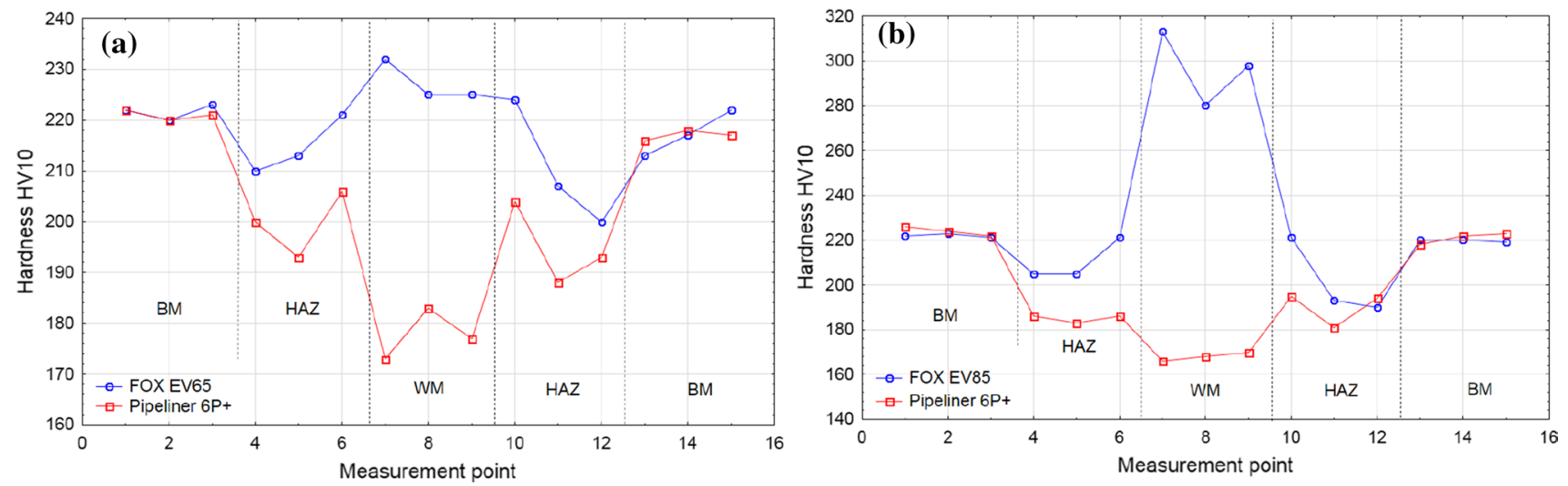

Fig. 22 Results of hardness tests for MMA girth welded joints, a filler metal FOX EV65 and Pipeliner 6P+, b filler material FOX EV85 and Pipeliner 6P+

Fig. 23 Hardness map (HV0.05) of MAG girth welded joints: a Carbofil MnMo, b LMN MoNiVa
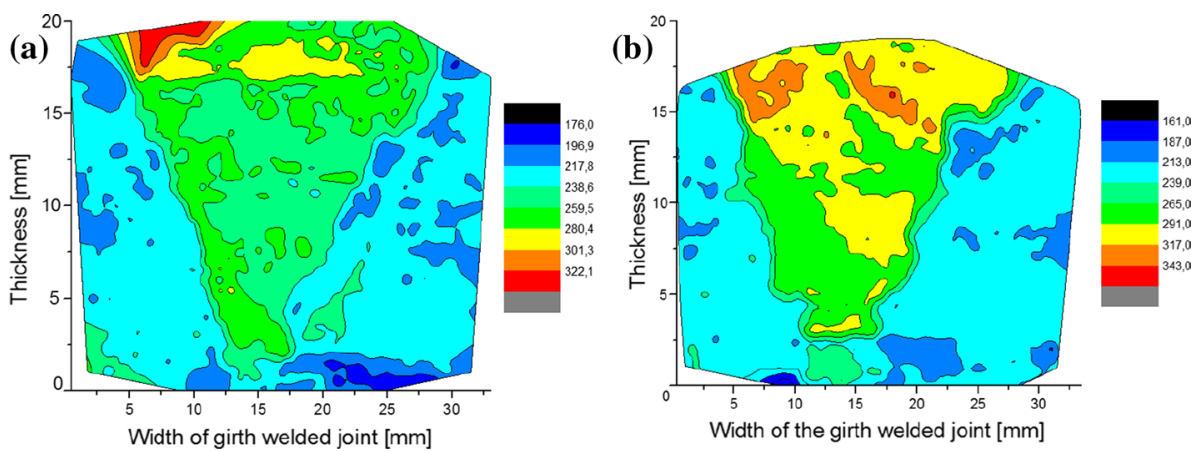
Table 7 Mechanical properties of girth welded joints, MAG welding process

\begin{tabular}{|c|c|c|c|c|c|c|c|c|c|c|c|}
\hline \multicolumn{3}{|l|}{ Specimen } & \multicolumn{9}{|c|}{ Mechanical properties } \\
\hline \multirow[t]{2}{*}{ No } & \multicolumn{2}{|l|}{ Dimension } & \multirow[t]{2}{*}{$F_{\mathrm{m}}(\mathrm{kN})$} & \multirow[t]{2}{*}{$R_{\mathrm{m}}(\mathrm{MPa})$} & \multirow[t]{2}{*}{ Bend angle $\left(^{\circ}\right)$} & \multicolumn{6}{|c|}{ Impact energy $(\mathrm{J}) /$ toughness $\left(\mathrm{J} / \mathrm{cm}^{2}\right)$} \\
\hline & $a_{0} \times b_{0}(\mathrm{~mm})$ & $S_{0}\left(\mathrm{~mm}^{2}\right)$ & & & & $+20^{\circ} \mathrm{C}$ & & & $-10^{\circ} \mathrm{C}$ & & \\
\hline \multicolumn{12}{|c|}{ Carbfil MnMo (PA) } \\
\hline $2 \mathrm{~A} / \mathrm{R} / 1$ & $17.0 \times 24.8$ & 421.6 & 265.7 & $630.3^{*}$ & & & & & & & \\
\hline $2 \mathrm{~A} / \mathrm{R} / 2$ & $17.0 \times 24.8$ & 421.6 & 268.8 & $637.6^{*}$ & & & & & & & \\
\hline 2A/FBB & $16.4 \times 26.4$ & 433.0 & & & 180 & & & & & & \\
\hline $2 \mathrm{~A} / \mathrm{RBB}$ & $16.3 \times 26.8$ & 436.8 & & & 180 & & & & & & \\
\hline 2F/VWT & $8.0 \times 10.0$ & 80.0 & & & & $\begin{array}{l}154 \\
192.5\end{array}$ & $\begin{array}{l}140 \\
175.0\end{array}$ & $\begin{array}{l}132 \\
165.0\end{array}$ & $\begin{array}{l}104 \\
130.0\end{array}$ & $\begin{array}{l}108 \\
135.0\end{array}$ & $\begin{array}{l}122 \\
152.5\end{array}$ \\
\hline $2 \mathrm{~F} / \mathrm{VHT}$ & $8.0 \times 10.0$ & 80.0 & & & & $\begin{array}{l}136 \\
170.0\end{array}$ & $\begin{array}{l}148 \\
185.0\end{array}$ & $\begin{array}{l}146 \\
182.5\end{array}$ & $\begin{array}{l}130 \\
162.5\end{array}$ & $\begin{array}{l}90 \\
112.5\end{array}$ & $\begin{array}{l}164 \\
205.0\end{array}$ \\
\hline 2F/VHT 2 & $8.0 \times 10.0$ & 80.0 & & & & $\begin{array}{l}216 \\
270.0\end{array}$ & $\begin{array}{l}226 \\
282.5\end{array}$ & $\begin{array}{l}210 \\
262.5\end{array}$ & $\begin{array}{l}136 \\
170\end{array}$ & $\begin{array}{l}190 \\
237.5\end{array}$ & $\begin{array}{l}212 \\
265.0\end{array}$ \\
\hline 2F/VHT 5 & $8.0 \times 10.0$ & 80.0 & & & & $\begin{array}{l}224 \\
280.0\end{array}$ & $\begin{array}{l}224 \\
280.0\end{array}$ & $\begin{array}{l}226 \\
282.5\end{array}$ & $\begin{array}{l}228 \\
285.0\end{array}$ & $\begin{array}{l}220 \\
275.0\end{array}$ & $\begin{array}{l}212 \\
262.0\end{array}$ \\
\hline \multicolumn{12}{|c|}{ LMN MoNiVa (PA) } \\
\hline $1 \mathrm{~A} / \mathrm{R} / 1$ & $16.7 \times 24.9$ & 415.8 & 271.1 & $652.0^{*}$ & & & & & & & \\
\hline $1 \mathrm{~A} / \mathrm{R} / 2$ & $17.0 \times 24.9$ & 423.3 & 276.1 & $652.3^{*}$ & & & & & & & \\
\hline $1 \mathrm{~A} / \mathrm{FBB}$ & $15.9 \times 26.7$ & 424.5 & & & 180 & & & & & & \\
\hline $1 \mathrm{~A} / \mathrm{RBB}$ & $16.3 \times 26.5$ & 432.0 & & & 180 & & & & & & \\
\hline 1F/VWT & $8.0 \times 10.0$ & 80.0 & & & & $\begin{array}{l}102 \\
127.5\end{array}$ & $\begin{array}{l}108 \\
135.0\end{array}$ & $\begin{array}{l}100 \\
125.0\end{array}$ & $\begin{array}{l}98 \\
122.5\end{array}$ & $\begin{array}{l}88 \\
110.0\end{array}$ & $\begin{array}{l}84 \\
105.0\end{array}$ \\
\hline $1 \mathrm{~F} / \mathrm{VHT}$ & $8.0 \times 10.0$ & 80.0 & & & & $\begin{array}{l}120 \\
150.0\end{array}$ & $\begin{array}{l}136 \\
170.0\end{array}$ & $\begin{array}{l}222 \\
277.5\end{array}$ & $\begin{array}{l}94 \\
117.5\end{array}$ & $\begin{array}{l}96 \\
120.0\end{array}$ & $\begin{array}{l}88 \\
110.0\end{array}$ \\
\hline 1F/VHT 2 & $8.0 \times 10.0$ & 80.0 & & & & $\begin{array}{l}206 \\
257.5\end{array}$ & $\begin{array}{l}198 \\
247.5\end{array}$ & $\begin{array}{l}210 \\
262.5\end{array}$ & $\begin{array}{l}102 \\
127.5\end{array}$ & $\begin{array}{l}96 \\
120.0\end{array}$ & $\begin{array}{l}96 \\
120.0\end{array}$ \\
\hline 1F/VHT 5 & $8.0 \times 10.0$ & 80.0 & & & & $\begin{array}{l}216 \\
270.0\end{array}$ & $\begin{array}{l}180 \\
225.0\end{array}$ & $\begin{array}{l}210 \\
262.5\end{array}$ & $\begin{array}{l}196 \\
245.0\end{array}$ & $\begin{array}{l}192 \\
240.0\end{array}$ & $\begin{array}{l}200 \\
250.0\end{array}$ \\
\hline
\end{tabular}

Identifications of test specimens: R/1 and R/2, specimens for tensile tests; FBB, face bend test of the butt welds; RBB, root bend test of the butt welds; VWT, impact test: V, Charpy-V notch; W, notch in weld metal; T, notch through thickness; VHT, impact test: Charpy-V notch; H, notch in heat-affected zone; T, notch through thickness; VHT 2, impact test: Charpy-V notch; H, notch in heat-affected zone; T, notch through thickness; 2, 5, $2 \mathrm{~mm}$ and $5 \mathrm{~mm}$ from the fusion line

Tensile tests: * rupture out of the welded metal, bend test: $d=4 \mathrm{~g}, d=60 \mathrm{~mm}$

Table 8 Mechanical properties of MAG filler materials [43, 44]

\begin{tabular}{lllll}
\hline Filler material & $R_{\mathrm{m}}(\mathrm{MPa})$ & $\begin{array}{l}\mathrm{HV} 10 \text { from } \\
R_{\mathrm{m}}\end{array}$ & $R_{\mathrm{e}}(\mathrm{MPa})$ & $\mathrm{HV} 10$ from $R_{\mathrm{e}}$ \\
\hline $\begin{array}{l}\text { LMN } \\
\text { MoNiVa }\end{array}$ & 831.0 & 269.6 & 766.1 & 299.6 \\
$\begin{array}{l}\text { Carbofil } \\
\text { MnMo }\end{array}$ & 697.2 & 225.0 & 631.9 & 242.5 \\
\hline
\end{tabular}

and hardness is observed (Table 5, Fig. 22). In root pass the same filler material was applied, thus the hardness is almost the same, but lower than in cap passes. In the root passes (bottom part) ferrite prevails with a grain size of several dozen micrometres. On the borders of ferrite grains, a second structural component, occurring as small islands of a few micrometres in diameter, can be distinguished. This is perlite. Therefore, the hardness is lower than cap passes about 180 HV5.

For MAG welded joints, similar as for MMA welded joints the chemical composition of filler materials [26, 28] decided about microstructure as well as mechanical properties of weld metals. The microstructure of the weld metal fabricated with LMN MoNiVa constitutes fine bainite. The hardness of the weld metal is $320 \mathrm{HV} 1$, which well corresponds to the observed microstructure. On the other side, for Carbfil MnMo MAG welded joint the microstructure is characterized by a larger primary austenite grain. Moreover, on the primary boundaries the ferrite appears as a continuous phase or the Widmanstätten ferrite with plates growing into the grain interior. In this case, the hardness of the weld metal is lower than $260 \mathrm{HV} 1$ and the strength of welded joint is lower than for LMN MoNiVa filler material. 

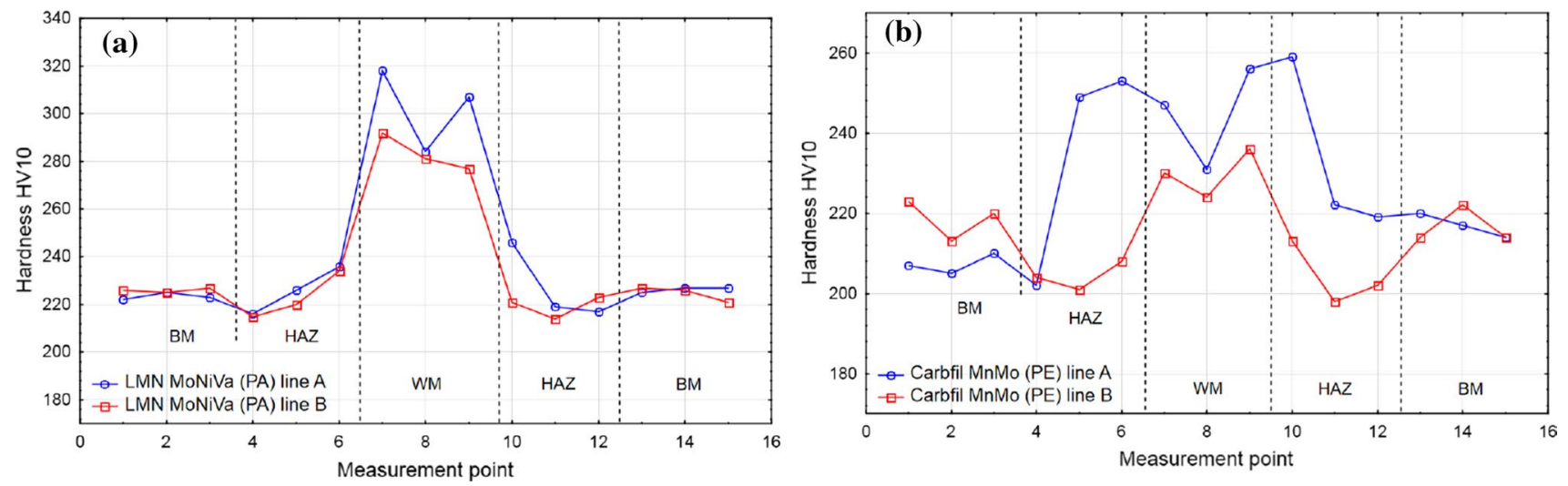

Fig. 24 Results of hardness tests for MAG girth welded joints, a LMN MoNiVa, b Carbofil MnMo

The difference in microstructure and hardness distribution correspond also to impact energy (see Table 4). The even match material Carbfil MnMo provides higher toughness than overmatch LMN MoNiVa filler material. Moreover, the heat input (Table 4) for MAG welded joint with LMN MoNiVa is a little bit higher than for Carbfil MnMo filler material. Therefore, the impact energy is lower, but hardness is higher (Fig. 24).

It can be noted, that based on the achieved results the proper selection of welding technology and filler material determine the final mechanical properties of girth welded joints. In case of demand of the highest strength of welded joints the overmatch material should be applied (MMA FOX EV85 and MAG LMN MoNiV). In the other side if the toughness is the most important factor for engineers the FOX EV65 filler material has to be used.

\section{Conclusion}

The purpose of the study was to determine the differences in microstructure and mechanical properties of the girth welded joints resulted from the welding technology and the applied filler materials. From the investigation, the following conclusions were drawn:

- the HAZ of the MMA welded joints is not homogeneous-near the fusion line the zone the grains are coarse while farther-fine. Ferrite in various morphologies, bainite, perlite, austenitic-martensitic islands (M/A) can be distinguished in the microstructure. In the area of root passes the microstructure consists of recrystallized ferrite grains, and in the filler passes (another filler material was used) the fine bainitic microstructure can be observed.
- in the case of MAG welded joints the weld microstructure consists of primary austenite grains with some ferrite on the primary boundaries. This ferrite is in the form a continuous phase or Widmanstätten ferrite, which lathes grow towards the grain interiors. The microstructure of the HAZ varies continuously from the coarse-through the fine-grained structure to the microstructure of the base material,

- the hardness maps and hardness distribution confirm the welded joints' heterogeneity. The experimental hardness measurements correspond with values calculated from strength properties. The strong heterogeneity of the girth welded joints in HAZ as well as weld metal is observed. The MMA girth welded joints exhibit higher heterogeneity,

- out of the two welding processes considered, the MAG process with LMN MoNiV filler resulted in the highest hardness $(320 \mathrm{HV})$ in the weld corresponding to a microstructure of fine bainite and the highest impact strength is obtained in the MMA weld made with FOX EV65 filler (110-130 J at $\left.-10^{\circ} \mathrm{C}\right)$,

- the MMA process with FOX EV85 filler resulted in the highest strength (656.5 and 675.0 MPa)-rupture out of the welded metal, the MMA process with FOX EV65 filler resulted in the lowest strength (634.1 and 633.7 MPa)—rupture in the welded metal.

Acknowledgements The authors would like to thank Research Fund for Coal and Steel (RFCS). The research was performed within the framework of the SBD-SPipe Project, Grant Agreement Number: RFSR-CT-2013-00025 entitled "Strain-based design of spiral-welded pipes for demanding pipeline applications". Research work supported by the financial resources for science in the years 2013-2016 granted for the realisation of an international co-financed project Contract No. 3000/FBWiS/13/2014/2.

Funding Research Fund for Coal and Steel as well as Ministry of Science and Higher Education. 


\section{Compliance with ethical standards}

Conflict of interest The authors declare that they have no conflict of interest.

Ethical statement Authors state that the research was conducted according to ethical standards.

Open Access This article is licensed under a Creative Commons Attribution 4.0 International License, which permits use, sharing, adaptation, distribution and reproduction in any medium or format, as long as you give appropriate credit to the original author(s) and the source, provide a link to the Creative Commons licence, and indicate if changes were made. The images or other third party material in this article are included in the article's Creative Commons licence, unless indicated otherwise in a credit line to the material. If material is not included in the article's Creative Commons licence and your intended use is not permitted by statutory regulation or exceeds the permitted use, you will need to obtain permission directly from the copyright holder. To view a copy of this licence, visit http://creativecommons.org/licenses/by/4.0/.

\section{References}

1. Honore A. The outlook for natural gas demand in Europe, the Oxford Institute for Energy Studies; 2014.

2. Klimpel A. Assessment of the advisability of the use of steel pipes X70 and X80 for strategic pipelines of large diameters with respect to their weldability. Weld Int. 2014;28:953-6.

3. Baker TN. Microalloyed steels. Ironmak Steelmak. 2016;43:264-307.

4. Mendoza R, Huante J, et al. Development of an API 5L X-70 grade steel for sour gas resistance pipeline application. J Mater Eng Perform. 1999;8:549-55.

5. Weertman JR. Hall-Petch strengthening in nanocrystalline metals. Mater Sci Eng A. 1993;166:161-7.

6. Li Ch, Wang Y, et al. Microstructure and toughness of coarse grain heat affected zone of domestic X70 pipeline steel during in-service welding. J Mater Sci. 2011;46:727-33.

7. Shin SJ, Hwang B, et al. Correlation of microstructure and charpy impact properties in API X70 and X80 line-pipe steels. Mater Sci Eng A. 2007;458:281-9.

8. Sohn SS, Han SY, et al. Effects of microstructure and pipe forming strain on yield strength before and after spiral pipe forming of API X70 and X80 linepipe steel sheets. Mater Sci Eng A. 2013;573:18-26.

9. Wang J, Atrens A. Microstructure and grain boundary microanalysis of X70 pipeline steel. J Mater Sci. 2003;38:323-30.

10. Ghomashchi R, Costin W, Kurji R. Evolution of weld metal microstructure in shielded metal arc welding of X70 HSLA steel with cellulosic electrodes: a case study. Mater Charact. 2015;107:317-26.

11. Beidokhti B, Kokabi AH, Dolati A. A comprehensive study on the microstructure of high strength low alloy pipeline welds. J Alloys Compd. 2014;597:142-7.

12. Bordbar S, Alizadeh M, Hashemi SH. Effects of microstructure alteration on corrosion behavior of welded joint in API X70 pipeline steel. Mater Des. 2013;45:597-604.

13. Mohammadijoo M, Valloton J, et al. Characterization of martensite-austenite constituents and micro-hardness in intercritical reheated and coarse-grained heat affected zones of API X70 HSLA steel. Mater Charact. 2018;142:321-31.
14. de Moraes CAP, Chludzinski M, et al. Residual stress evaluation in API 5L X65 girth welded pipes joined by friction welding and gas tungsten arc welding. J Mater Res Technol. 2018;8:988-95.

15. Giorgetti V, Santos EA, et al. Stress corrosion cracking and fatigue crack growth of an API 5L X70 welded joint in an ethanol environment. Int J Press Vessels Pip. 2019;169:223-9.

16. Digheche $\mathrm{K}$, Boumerzoug $\mathrm{Z}$, et al. Influence of heat treatments on the microstructure of welded API X70 pipeline steel. Acta Metall Slovaca. 2017;23:72-8.

17. Maamache B, Bouabdallah $\mathrm{M}$ et al. Characterization of a welded joint in steel API.5L.X70 having undergone successive repairs. In: Materials science engineering MSE, 25-27 September 2012, Darmstadt, Germany.

18. Vega OE, Hallen JM, et al. Effect of multiple repairs in girth welds of pipelines on the mechanical properties. Mater Charact. 2008;59:1498-507.

19. Bally J, De Waele W, et al. Characterisation of weld heterogeneity through hardness mapping and miniature tensile testing. Int J Sustain Constr Des. 2015;6:1-8.

20. Hertelé S, Gubeljak N, De Waele W. Advanced characterization of heterogeneous arc welds using micro tensile tests and a twostage strain hardening ('UGent') model. Int J Press Vessels Pip. 2014;119:87-94.

21. PN-EN ISO 3183:2013-05. Petroleum and natural gas industries. Steel pipe for pipeline transportation systems.

22. Data of filler material EV65, Böhler.

23. AWS A5.5/A5.5M:2014, Specification for Low-Alloy Steel Electrodes for Shielded Metal Arc Welding.

24. Data of filler material EV85, Böhler.

25. Data of filler metal Pipeliner 6P+, Lincoln Electric.

26. AWS A5.1/A5.1M: 2012, Specification for carbon steel electrodes for shielded metal arc welding.

27. Data of filler metal Carbofil MnMo, Oerlikon.

28. AWS A5.28/A5.28M:2005, Specification for low-alloy steel electrodes and rods for gas shielded arc welding.

29. Data of filler metal LNM MoNiVa, Lincoln Electric.

30. EN 1011-1:2009 Welding. Recommendations for welding of metallic materials. Part 1: General guidance for arc welding.

31. PN-EN ISO 4136: 2013-05. Destructive tests on welds in metallic materials. Transverse tensile test.

32. PN-EN ISO 148-1: 2010. Metallic materials. Charpy pendulum impact test. Part 1: Test method.

33. PN-EN ISO 9016: 2013-05. Destructive tests on welds in metallic materials. Impact tests. Test specimen location, notch orientation and examination.

34. PN-EN ISO 9015-1: 2011. Destructive tests on welds in metallic materials. Hardness testing. Part 1: Hardness test on arc welded joint.

35. PN-EN ISO 6507-1: 2007. Metallic materials. Vickers hardness test. Part 1: Test method.

36. PN-EN ISO 5173:2010. Destructive tests on welds in metallic materials. Bend tests.

37. PN EN ISO 17639 Destructive tests on welds in metallic materials. Macroscopic and microscopic examination of welds.

38. Shukla R, Ghosh SK, et al. Microstructure, texture, property relationship in thermo-mechanically processed ultra-low carbon microalloyed steel for pipeline application. Mater Sci Eng A. 2013;587:201-8.

39. Onsoien MI, M'hamdi M, Mo M. A CCT diagram for an offshore pipeline steel of X70 type. Weld J. 2009;88:1s-6s.

40. Godefroid LB, Cândido LC, et al. Microstructure and mechanical properties of two API steels for iron ore pipelines. Mater Res. 2014;17:114-20.

41. Zhu Z, Han J, Li H. Effect of alloy design on improving toughness for X70 steel during welding. Mater Des. 2015;88:1326-33. 
42. Niu J, Qi LH, et al. Tempering microstructure and mechanical properties of pipeline steel X80. Trans Nonferrous Met Soc China. 2009;19:573-8.

43. PN-EN 15653:2018. Metallic materials. Method of test for the determination of quasistatic fracture toughness of welds.

44. Final report of SPipe project. Strain-based design of spiral-welded pipes for demanding pipeline applications, RFSR-CT-201300025, 2017.

45. Tabor D. The hardness of metals. Oxford: Clarendon Press; 1951.

46. Węglowski MSt, Zeman M, et al. Physical simulation of weldability of Weldox 1300 Steel. Mater Sci Forum. 2013;762:551-5.
47. Węglowski MSt, Zeman M, Grocholewski A. Effect of welding thermal cycles on microstructure and mechanical properties of simulated heat affected zone for a Weldox 1300 ultra-high strength alloy steel. Arch Metall Mater. 2016;61:127-31.

Publisher's Note Springer Nature remains neutral with regard to jurisdictional claims in published maps and institutional affiliations. 